\title{
Biopesticides and Their Role in Sustainable Agricultural Production
}

\author{
Geraldin M. W. Lengai*, James W. Muthomi \\ Department of Plant Science and Crop Protection, University of Nairobi, Nairobi, Kenya \\ Email: *lingaig@gmail.com
}

How to cite this paper: Lengai, G.M.W. and Muthomi, J.W. (2018) Biopesticides and Their Role in Sustainable Agricultural Production. Journal of Biosciences and Medicines, 6, 7-41.

https://doi.org/10.4236/jbm.2018.66002

Received: April 1, 2018

Accepted: June 4, 2018

Published: June 7, 2018

Copyright ( 2018 by authors and Scientific Research Publishing Inc. This work is licensed under the Creative Commons Attribution International License (CC BY 4.0).

http://creativecommons.org/licenses/by/4.0/

(c) (i) Open Access

\begin{abstract}
Biopesticides are derivatives of plants, microorganisms and insects. Substances from plants and animals have been used to manage diseases in crops, animals and humans. Reliance on nature to heal nature is a practise for many people around the world. Use of natural products was overtaken by synthetic chemicals due to their efficacy, reliability and quick knock down effect. However, synthetic pesticides have become a health hazards for humans and environment due to their toxicity and pollution. Biopesticides are potential alternatives to synthetic pesticides. Sources of biopesticides are readily available, easily biodegradable, exhibit various modes of action, are less expensive and have low toxicity to humans and non-target organisms. Neem, pyrethrum, cotton and tobacco are known sources of botanical pesticides and have already been commercialized. Other sources of botanical pesticides include garlic, euphorbia, citrus, pepper among others. Species of Trichoderma, Bacillus, Pseudomonas, Beauveria have been commercialized as microbial pesticides. Biopesticides are however faced with challenges of formulation, registration, commercialization, acceptance and adoption. This paper describes several aspects of biopesticide development, including but not limited to, their sources, production, formulation, commercialization, efficacy and role in sustainable agriculture.
\end{abstract}

\section{Keywords}

Biopesticides, Conservation Agriculture, Integrated Pest Management, Environmental Safety

\section{Introduction}

Biopesticides are products and by-products of naturally occurring substances such as insects, nematodes, microorganisms, plants as well as semiochemicals [1]. Based on the nature and origin of the active ingredients, biopesticides fall 
into several categories such as botanicals, antagonists, compost teas, growth promoters, predators and pheromones [2]. Plants and microorganisms are the major sources of biopesticides due to the high components of bioactive compounds and antimicrobial agents [3]. The active compounds in plants include phenols, quinones, alkaloids, steroids, terpenes, alcohols and saponins [4]. Different plant families have varied antimicrobial bioactive compounds which include oil components such as $\alpha$ - and $\beta$-phillandrene, limonene, camphor, linalool, $\beta$-caryophyellene and linalyl acetate depending on the plant family [5] [6]. Microbial biopesticides include bacteria species such as Pseudomonas, Bacillus, Xanthomonas, Rahnella and Serratia or fungi such as Trichoderma, Verticillium and Beauveria species [7]. Biopesticides exhibit different modes of action against pathogens such as hyperparasitism, competition, lysis and predation [8].

Plant growth promoting rhizobacteria protect plants from biotic and abiotic stresses and they also enhance plant growth and enhance formation of root hairs [9]. The most common species of plant growth promoting rhizobacteria include Agrobacterium, Ensifer, Microbacterium, Bacillus, Rhizobium, Pseudomonas, Chryseobacterion and Rhodococcus [10]. They colonize the environment around the plant roots, fix nitrogen, increase phosphate solubilisation and result in general increase in plant yield [11]. Species of Pseudomonas and Bacillus have been used as biofertilizers with reports showing increase in plant growth, yield and phosphorous and zinc content in fruits and soils [12]. Natural enemies including predators, pathogens and some insects are also used as biopesticides in management of insect pests. Parasitoids, wasps, beetles, lace wings, bugs and lady birds are used in management of destructive pests such as boll worms (Helicoverpa armigera) in important crops such as cotton [13] [14]. Compost teas are filtrates of compost extracts and are similarly used as biopesticides [15].

This review discusses the current status of knowledge on biopesticides including their sources, production, formulation, commercialization, role in sustainable agriculture and their limitations. It also brings together the different types of biopesticides and evidences of their use against important pests in different crops.

\section{Limitations and Challenges in the Use of Conventional Pesticides}

There are harmful effects associated with the use of synthetic pesticides such as toxicity and poisoning [16]. Synthetic pesticides also lead to environmental pollution due to the unbiodegradable nature of their constituent compounds [17]. According to Parliman [18], degradation of metham sodium and other fumigants was reported to last up to over six months after application. In a report by PAN [19], metham sodium pollutes the air and soil thereby affecting the population of natural enemies in the soil. Methyl bromide has been banned from agricultural use due to its negative impact on the environment. It is associated with depletion of ozone layer which contributes significantly to climate change [20]. The constituent compounds of chemical pesticides contaminate soils rendering 
them unsuitable for crop production [21]. They also pollute surface and ground water, killing aqua life after inhalation and consumption [22]. Use of dichloro diphenyl trichloroethane (DDT) for instance led to poisoning of birds, marine species and humans. It has been reported to have carcinogenic properties leading to its ban from agricultural use [23].

Continuous use of synthetic pesticides leads to development of resistant plant pathogen strains leading to their resurgence. Farmers apply more chemicals in an effort to eradicate such pests [24] [25]. In the process of managing target pests, synthetic pesticides kill non-target beneficial organisms such as pollinators, predators and antagonists thereby disrupting biodiversity [26] [27]. After application, the active compounds of the synthetic pesticides are taken up and retained by crops. Consumption of such crops poses chronic health problems to humans due to the accumulated toxic chemical residues [28]. Exposure to pesticides adversely affects the human population, directly or indirectly. For example, pesticides containing Malathion and Trichlorfon have been reported to cause reproductive complications in humans [29]. Exposure to some pesticides have also been reported to retard growth, induce chemical and structural changes in body organs as well as disturb immune responses. They also reduce resistance of animals to disease-causing pathogen infections [22]. Continuous exposure to pesticides such as chloropyrifos cause gene mutations, genetic damages, reproductive health problems and chronic diseases such as asthma, hypertension and cancer [30] [31].

In a study by Xavier et al., [32], application of Fenpyroximate on chilli peppers (Capsicum annum $\mathrm{L}$ ) resulted in retention of its residues even after sun drying and processing. Similarly, spinosad (spinosyn A and spinosyn D), Indoxacarb and Deltamethrin containing insecticides used to control Rhizoctonia dominica, Sitophilus oryzae and Trogoderma granarium were found to be persistent for up to 120 days after application [33].

The horticulture sector in many developing countries has been particularly adversely affected by the use of synthetic pesticides. The European Union (EU) set out strict regulations regarding levels of pesticide residues and safety of agricultural produce exported to their markets. The use of pesticides containing Dimethoate on vegetables was banned by EU. Failure to comply with this regulation led to rejection and destruction of fresh vegetable consignments containing chemical residues above the required limits [34]. Residues of the restricted chemicals should not exceed 0.02 parts per million ( $\mathrm{ppm}$ ) in a sample of vegetables. The percentage of inspection was increased to $10 \%$ on fresh produce at ports of entry into the European Union [35]. According to European Commission [36], Maximum Residue Levels (MRLs) of unknown pesticides should not exceed $0.01 \mathrm{mg} / \mathrm{Kg}$ and there was imposed a $10 \%$ sampling per consignment in fresh beans and pods. Interceptions of fresh produce almost ruined Kenya's export market reputation due to presence of traces of banned pesticides [37]. Following the guidelines made by the $\mathrm{EU}$ and the losses incurred due to rejection and destruction of fresh vegetable consignments, there was a reduction in vo- 
lumes of horticultural exports. This negatively affected the livelihoods of small holder farmers who are the major producers of vegetable crops [38]. This led to introduction of a cloud-based traceability system which uses a quick reference (QR) code and GPS coordinates to pinpoint the individual farmer whose consignment fails to comply with regulations [39]. This has resulted in increase of the cost of production and several farmers opted out of the export business.

\section{Biopesticides of Botanical Origin}

Based on the method of extraction, botanical pesticides can either be plant extracts or essential oils [6]. They are obtained from plants parts such as leaves, barks, flowers, roots, rhizomes, bulbs, seeds, cloves or fruits which are either fresh or dried. Dried plant parts are preferred as this reduces water concentration resulting in higher yield of active ingredient [40]. A Gas Chromatography-Mass Spectrometry (GC-MS) analysis was carried out on Citrus sinensis and d-limonene and myrcene were reported as the major constituents of the oil component. The products were tested against a cereal leaf beetle (Oulema melanopus) on wheat and a mortality of up to $85 \%$ was reported on larvae observed in 48 hours [41]. Aqueous fruit extracts of Withania somnifera were tested for activity against Fusarium oxysporum f.sp. radicis-lycopersici, the causal agent of fusarium crown and root rot disease in tomatoes. At a concentration of $2 \%$ the extracts inhibited growth of the fungal pathogen by up to $56 \%$ in vitro [3].

Table 1 shows examples of plants reported to have potential as sources of botanical pesticides and respective target pests. In vitro experiments involving several ethanolic plant extracts, turmeric (Curcuma longa), lemon (Citrus limon), garlic (Allium sativum), pepper (Capsicum frutescens) and ginger (Zingiber officinale) were reported to be significantly effective against Alternaria solani, $P y$ thium ultimum, Rhizoctonia solani and Fusarium oxysporum f. sp. lycopersici [42]. Turmeric (Curcuma longa) was reported to be the most effective with a growth inhibition of up to $73 \%$ against Alternaria solani. Pseudomonas syringae p.v. tomato was effectively managed in vitro by Rhus coriaria, Eucalyptus globulus and Rosmarinus officinalis [43]. Eucalyptus globulus was reported efficacious in preventing the bacterial speck of tomato (Pseudominas syringae p.v. tomato) by up to $65 \%$ under greenhouse conditions. At $5 \%$ concentration, a mortality rate of up to $78 \%$ was reported on juveniles of root knot nematodes (Meloidogyne sp) by extracts of Nerium oleander. When the concentration was increased to $10 \%$ a mortality of between $65 \%-100 \%$ was observed on second stage juveniles treated with extracts of Eucalyptus sp, Cinnamomum verum, Nerium oleander, Azadirachta indica, Zingiber officinale and Allium sativum [44]. The most common and already commercialized botanical pesticides are derived from neem (Azadirachta indica), pyrethrum (Chrysanthemum cinerariifolium), sabadilla (Schoenocaulon officinale) and tobacco (Nicotiana tabacum) [45].

The quality of extracts and oils is highly dependent on the solvent used and method of extraction [46]. The solvents should be of low toxicity, able to dissolve as many compounds as possible, evaporate easily at low temperatures and 
Table 1. Plants with potential as botanical pesticides and respective target pests.

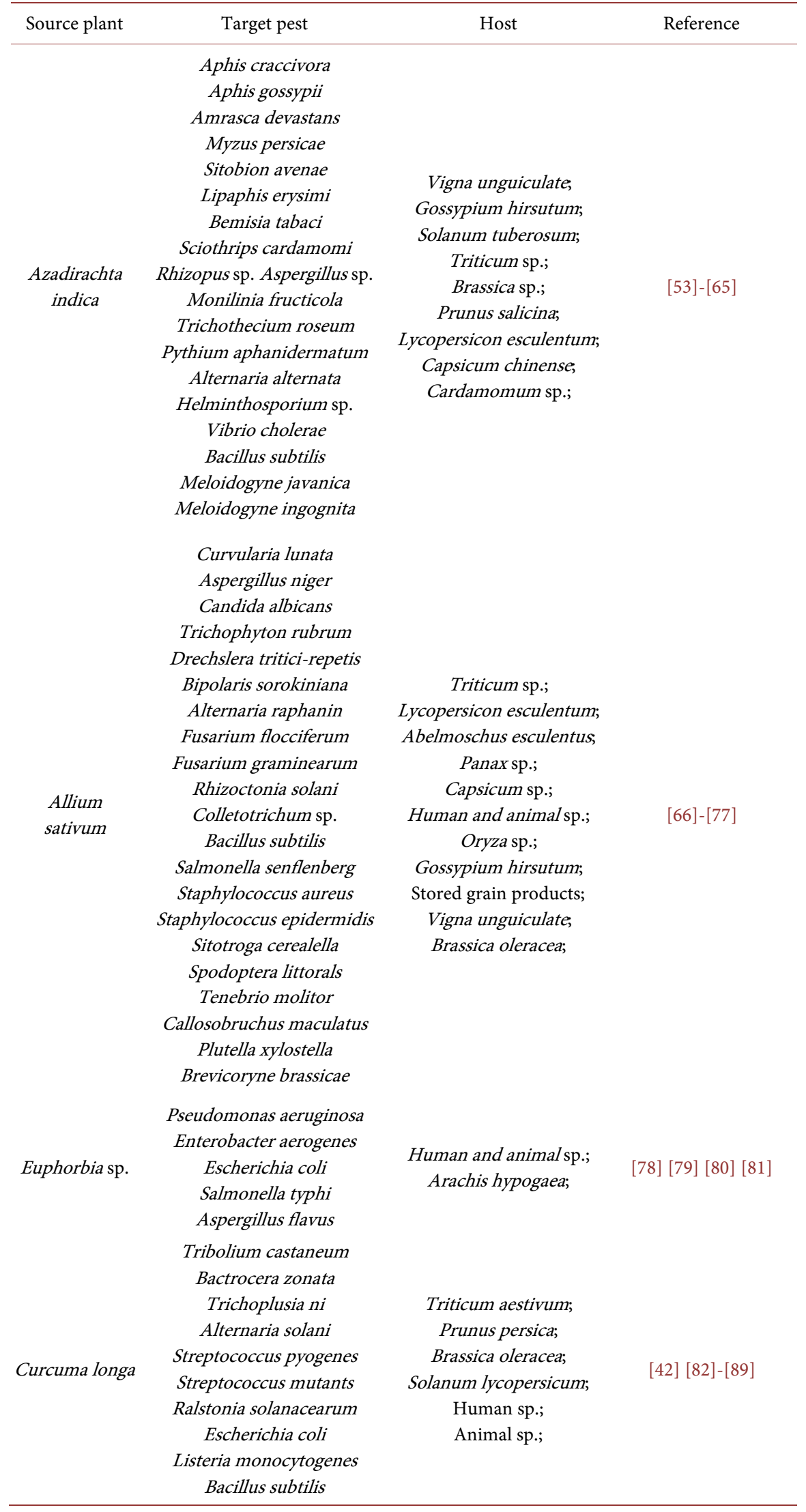




\section{Continued}

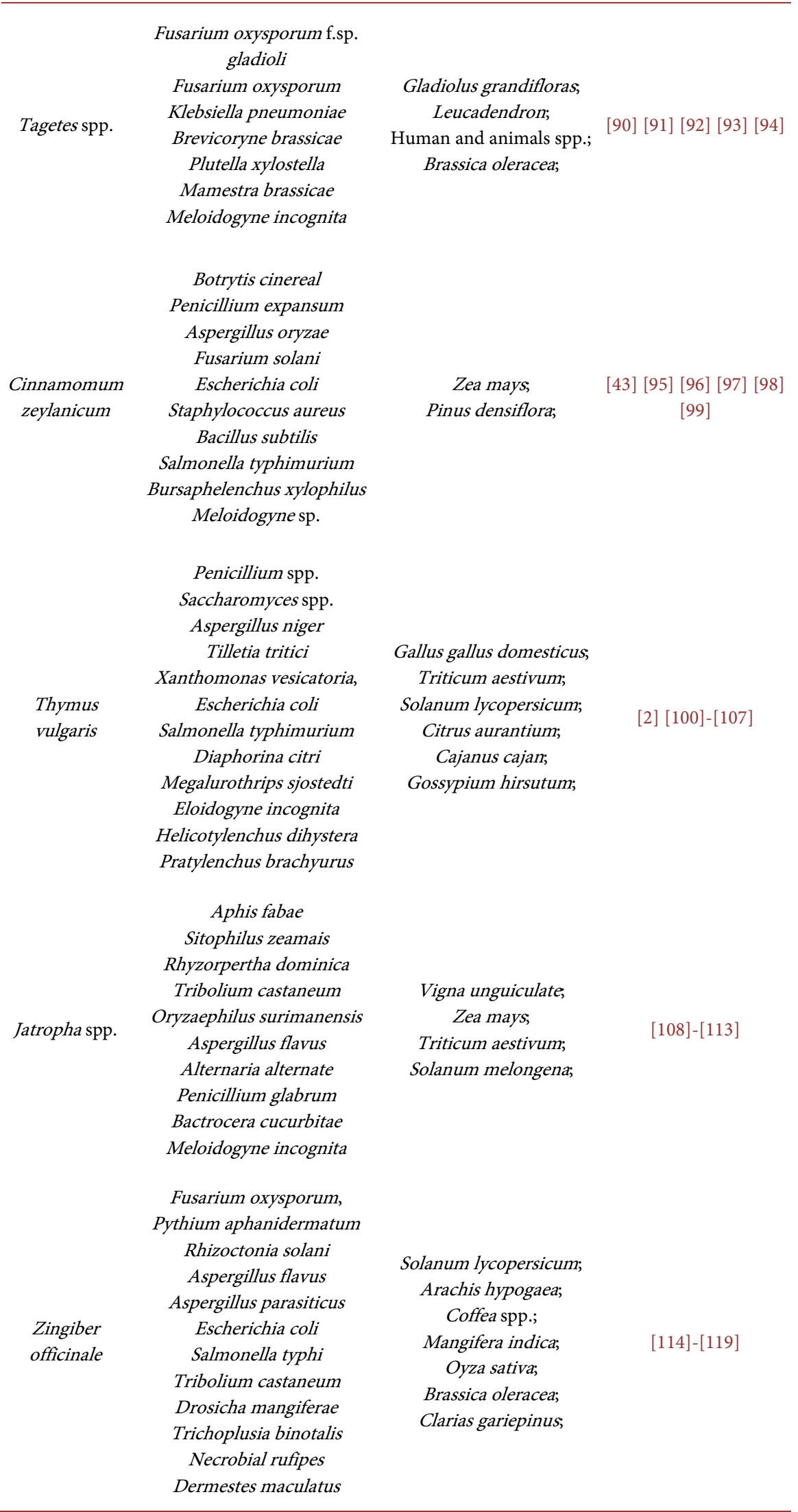


should preferably possess preservative properties [47]. The choice of solvent is dictated by the target active compounds. Although water is the universal solvent, it extracts less antimicrobial compounds compared to other solvents [48]. Organic solvents such as ethanol and methanol yield better extracts and their results are consistent. Other extraction solvents include dichlomethane, acetone and hexane [49]. According to a study by Wetungu et al., [50] methanol and hexane extracts from Tarchonanthus camphoratus gave higher growth inhibition capacity against Escherichia coli, Salmonella typhi, Staphylocccus aureus, Proteus mirabilis, Candida albicans and Klebsiella pneumoniae. Methanol was also reported to be efficient in extracting seed components of Morinda citrofolia and the extracts showed antibacterial activity of up to 63\% against Escherichia coli and Pseudomonas spp [51]. The differences among the different solvents are attributed to their polarity [52]. The plant parts from which the extracts are obtained also influences the quality of the extracts.

\section{Microorganisms as Sources of Biopesticides}

Microorganism-based biocontrol agents form the bulk of commercialized biopesticides and they include bacteria, viruses, fungi, nematodes and protozoa [120]. There are up to 175 reported microbial based biopesticide active agents and they have been used in management of pathogens, weeds, insects and nematodes [121]. Examples are illustrated in Table 2. Majority of the microbial biopesticides are used to manage soil borne pathogens [8]. Bacterial species that have been utilised as biopesticides include Bacillus, Pseudomonas, Burkholderia, Xanthomonas, Enterobacter, Streptomyces, Serratia and these are either obligate facultative or crystalliferous. Fungi used as biopesticides include species of Trichoderma, Beauveria, Metarhizium, Paecilomyces, Fusarium, Pythium, Penicillim and Verticillium. Steinernama and Heterarhabditis are nematode species used to make biopesticides [7]. The mechanisms of action exhibited by microorganisms against plant pathogens include hyperparasitism, competition, secretion of volatile compounds, antibiosis and parasitism [122].

The major sources of microorganisms with pesticidal activity are agricultural fields where they co-exist with other microorganisms including pathogens and beneficial species [123]. The rhizosphere is usually concentrated with various classes of important microorganisms. Other rich sources of microorganisms include hay, manure, cow shed, as well as straw [124]. Formulation of the microbial pesticides has a great contribution to the effectiveness of the resultant product and it is usually dependent on the substrate used. A study done by Adan et al., [125] showed that a formulation of Trichoderma harzianum prepared in black gram bran, peat soil and water had a high level of activity against damping off of eggplant seedlings caused by Sclerotium rolfsii. The activity was attributed to the high number of spores produced by the fungus.

According to Prasad and Syed [26], exposure of Helicoverpa armigera to conidial suspension of Beauveria bassiana resulted to antifeeding habits, blackening 
Table 2. Examples of microorganisms with potential as biopesticides.

\begin{tabular}{|c|c|c|c|}
\hline Microorganism & Target pest & Host & Reference \\
\hline $\begin{array}{l}\text { Trichoderma } \\
\text { spp. }\end{array}$ & $\begin{array}{c}\text { Penicillium stekii } \\
\text { Fusarium spp. } \\
\text { Ceratocystis radicicola } \\
\text { Pythium spp. } \\
\text { Alternaria spp. } \\
\text { Rhizoctonia spp. } \\
\text { Verticillium spp. } \\
\text { Mcrophomina phaseolina } \\
\text { Botrytis cinereal } \\
\text { Phytotphtora spp. } \\
\text { Meloidogyne spp. }\end{array}$ & $\begin{array}{l}\text { Lycopersicon esculentum; } \\
\text { Phoenix dactylifera; } \\
\text { Zea mays; } \\
\text { Gossypium hirsutum; } \\
\text { Solanum lycopersicon; } \\
\text { Solanum tuberosum; } \\
\text { Capsicum annum; } \\
\text { Solanum melongena; }\end{array}$ & [127]-[126] \\
\hline Beauveria spp. & $\begin{array}{c}\text { Dendrolimus tabulaeformis } \\
\text { Spodoptera litura } \\
\text { Uvarovistia zebra } \\
\text { Cyclocephala lurida } \\
\text { Frankliniella occidentalis } \\
\text { Hylobius abietis } \\
\text { Oryzaephilus surinamensis } \\
\text { Tuta absoluta } \\
\text { Polyphylla fullo }\end{array}$ & $\begin{array}{l}\text { Pinus tabulaeformis, } \\
\text { Phaseolus vulgaris; } \\
\text { Brassica oleracea; } \\
\text { Avena sativa; } \\
\text { Triticum aestivum }\end{array}$ & [137]-[146] \\
\hline $\begin{array}{l}\text { Paecilomyces } \\
\text { spp. }\end{array}$ & $\begin{array}{c}\text { Meloidogyne javanica } \\
\text { Phytophthora palmivora }\end{array}$ & $\begin{array}{c}\text { Solanum lycopersicon; } \\
\text { Vigna mungo; } \\
\text { Theobroma cacao; }\end{array}$ & [147]-[152] \\
\hline Bacillus spp. & $\begin{array}{l}\text { Macrophomina phaseolina } \\
\text { Fusarium graminearum } \\
\text { Colletotrichum spp. } \\
\text { Phaeomoniella chlamydospore } \\
\text { Fusarium solani } \\
\text { Meloidogyne incognita } \\
\text { Spodoptera frugiperda } \\
\text { Xanthomonas campestris pv. } \\
\text { campestris }\end{array}$ & $\begin{array}{c}\text { Glycine max; } \\
\text { Triticum aetivum; } \\
\text { Capsicum annuum; } \\
\text { Vitis vinifera; } \\
\text { Vicia faba; } \\
\text { Vigna mungo; } \\
\text { Solanum lycopersicon; }\end{array}$ & [153]-[163] \\
\hline $\begin{array}{l}\text { Metarhizium } \\
\text { spp. }\end{array}$ & $\begin{array}{c}\text { Musca domestica } \\
\text { Spodoptera litura } \\
\text { Ceratitis capitate } \\
\text { Polyphylla fullo } \\
\text { Tetranuchus urticae } \\
\text { Maruca vitrata } \\
\text { Tuta absoluta } \\
\text { Callosobruchus maculatus }\end{array}$ & $\begin{array}{c}\text { Citrus sinensis, } \\
\text { Polyphylla fullo; } \\
\text { Phaseolus vulgaris, } \\
\text { Solanum lycopersicon; }\end{array}$ & {$[146][164]-[170]$} \\
\hline $\begin{array}{l}\text { Pseudomonas } \\
\text { spp. }\end{array}$ & $\begin{array}{c}\text { Vibrio harveyi } \\
\text { Fusarium oxysporum } \\
\text { Alternaria alternata } \\
\text { Sclerotium rolfsii } \\
\text { Botryodiplodia theobromae } \\
\text { Rhizoctonia solani } \\
\text { Aspergillus aculatus } \\
\text { Dreshlera biseptata }\end{array}$ & $\begin{array}{l}\text { Mangifera indica; } \\
\text { Solanum lycopersicon; } \\
\text { Solanum melongena; } \\
\text { Vitis vinifera; } \\
\text { Oryza sativa; } \\
\text { Triticum aetivum; }\end{array}$ & $\begin{array}{c}{[171][172][173]} \\
\quad[174][175]\end{array}$ \\
\hline $\begin{array}{l}\text { Verticillium } \\
\text { spp. }\end{array}$ & $\begin{array}{c}\text { Trialeurodes vaporariorum } \\
\text { Bemicia tabaci }\end{array}$ & $\begin{array}{l}\text { Phaseolus vulgaris, } \\
\text { Euphorbia ulcherrima; }\end{array}$ & [176] [177] \\
\hline
\end{tabular}


of the body and the larvae becoming sluggish and morbid. The fungus finally consumes the entire larval tissues resulting in its death. Beric et al., [124] reported that isolates of Bacillus showed antagonistic activity against rice pathogen, Xanthomonas oryzae p.v. oryzae, and the activity was attributed to production of a bacteriocin by the bacterium. Treatment of wheat and rice plants with concentrations of Chaetomium globosum reduced the severity of wheat rust (Puccinia recondite) and rice blast (Magnaporthe grisea) by up to $80 \%$ [126]. Late blight (Phytophthora infestans) on tomato was also controlled by Chaetomium globosum by up to 50\% while mycelial growth of Pythium ultimum was inhibited in vitro in well diffusion assays. The activity of the fungus was attributed to production of two types of chaetoviridins, A and B [126]. These studies indicate that microbial biopesticides can be incorporated in integrated pest management for sustainable agriculture.

\section{Predators and Parasitoids as Biopesticides in Agriculture}

A predator kills and feeds on prey while parasitoids grow on or inside their hosts and eventually kill them [178]. The predators include beetles (Carabidae), ladybirds (Coccinellidae), spiders, lacewings (Chrysopidae) and true bugs while parasitoids mainly consist of wasps and other hemipterans [13]. Examples of predator organisms used in management of crop pests are presented in Table 3. These natural enemies are mainly found in the environment and are not evenly distributed. In order to have them in large numbers, they are either reared under controlled conditions and released into the fields or are multiplied in open fields containing the prey [179]. The most common way of rearing these predators is by growing them on their preferred hosts. This is either done in screen houses or growth chambers where the host plants are first grown and then exposed to pest infestation [180]. The predators are then introduced and they are maintained by growing on the prey [181]. Alternatively, the predators can be grown in cylinders where they are supplied with the prey and all other necessary conditions for growth are provided. An example is the mass rearing of Phytoseiulus persililis on Tetranychus urticae Koch [179]. The optimum growth of predator mite, Neoseiulus californicus, was observed when grown on an artificial diet supplemented with eggs of Ephestia kuehniella, Artemia franciscana cysts and maize bran [182]. Such artificial diets are important in reproduction, development and survival of the predators during rearing as well as reduction of production costs.

Predators can also be grown on egg masses of their prey or other suitable hosts which gives them a longer storage capacity. This has been employed in management of mealy bugs using parasitoids [183]. The predators can also be grown on other feeds such as rice bran as long as it provides the necessary nutrients to the insects [184]. Due to economic concerns, these organisms are reared on artificial media with carefully evaluated nutritional needs and requirements. Their growth media ranges from beef and liver to crushed lepidopteran pupae. These provide a combination of hormones and nutrients needed by 
Table 3. Examples of predator organisms used in management of crop pests.

\begin{tabular}{|c|c|c|c|}
\hline Predator & Target pest & Host & References \\
\hline Phytoseiulus spp. & $\begin{array}{l}\text { Tetranychus urticae } \\
\text { Tetranychus evansi }\end{array}$ & $\begin{array}{l}\text { Phaseolus vulgaris; } \\
\text { Solanum lycopersicon; } \\
\text { Fragaria ananassa; }\end{array}$ & [180] [189] [190] \\
\hline Neoseiulus spp. & $\begin{array}{l}\text { Tetranychus urticae } \\
\text { Oligonychus perseae }\end{array}$ & $\begin{array}{c}\text { Vicia faba; } \\
\text { Capsicum annuum; } \\
\text { Persea americana; }\end{array}$ & [191] [192] \\
\hline Amblyseius swirskii & Scirtothrips dorsalis & Capsicum sp.; & [193] \\
\hline Aphidius colemani & Aphis gossypii & $\begin{array}{c}\text { Dendranthema } \\
\text { grandiflora; }\end{array}$ & [194] \\
\hline Diglyphus isaea & Liriomyza huidobrensis & Solanum tuberosum; & [195] \\
\hline Encarsia formosa & Bemisia tabaci & Solanum lycopersicon; & [196] [197] \\
\hline
\end{tabular}

the predators for growth [185]. Artificial media provides as good nutrients as the host plants and reduces the cost of growing the plants. The artificial media is mostly used in laboratories and has been used for rearing Trichogramma and Anastatus spp [186].

An in vitro study by $\mathrm{Xu}$ and Enkegaard [187] showed that Amblyseius swirskii predated on Frankliniella occidentalis and Tetranychus urticae nymphs with preference to their first instars. The predation rate on T. urticae was $4-6$ nymphs in 12 hours. The authors reasoned that the outcome of the predation is highly dependent on several factors among them being the host plant traits. A synergistic effect on predation between Amblyseius swirskii and Phytoseiulus persimilis against two-spotted spider mite (Tetranychus urticae) with a mortality rate of up to $86 \%$ was reported by Fiedler [188]. Introduction of Amblyseius californicus and Amblyseius degenerans into a population of Tetranychus urticae under laboratory conditions recorded a mortality of up to $72 \%$ within 15 days.

\section{Production, Formulation and Commercialization of Biopesticides}

Botanical pesticides are prepared from plants and plant parts obtained from the environment, natural or man-made [198]. The materials are cleaned of dirt or foreign materials and then extracted either using solvents or distillation to obtain extracts or essential oils, respectively [199]. The resultant extracts are then subjected to screening for activity in vitro against different pests using different methods such as disc diffusion, agar well diffusion, agar dilution and poisoned food technique [200] [201]. The most active botanicals are then evaluated for efficacy in managing pests and diseases under field conditions. The active constituents of the selected extracts are then identified for optimum formulation [202]. Intensive laboratory and field trials conditions are carried out to ensure that the most efficacious combination of the active compounds, carrier materials, emulsifiers, surfactants and other components used in pesticide development are optimized. The efficacy report from the laboratory and field trials is used to request 
for registration of the product from the pest control products body. (Figure 1)

Production of microbial pesticides follows the same procedure as botanicals, except the that the antagonistic microorganisms are collected from sources like the cowshed, hay fields, rhizosphere, compost and manure [203]. They are isolated in to pure cultures in the laboratory and maintained in agar slants [204]. In vitro efficacy trials are carried out following methods such as dual culture, agar discs diffusion and agar well diffusion [205]. The active microorganisms are multiplied on a suitable substrate in the laboratory and mixed with carrier materials, enhancers and stabilizers for field application [206]. Repeated laboratory and field efficacy trials are conducted until registration process begins (Figure $1)$.

Before the natural products are commercialized, they are usually tested in the laboratory and under field conditions for efficacy against the target pests. The active compounds are also identified using techniques such as thin layer chromatography (TLC), high-performance liquid chromatography (HPLC) and gas chromatography-mass spectrometry (GC-MS) [207] [208]. Stabilizers and carrier materials are always added to the active compounds to enhance their applicability and longevity. Formulation of the active compounds should improve the stability of the compound as well as increase its efficiency and applicability. It should also reduce its degradability due to climatic factors such as heat, water and acids. Carrier materials majorly used include petroleum distillates, corn starch, talc, clays, and water. Emulsifiers such as soap are also added to the compounds during formulation and they are optimized to ensure effectiveness is

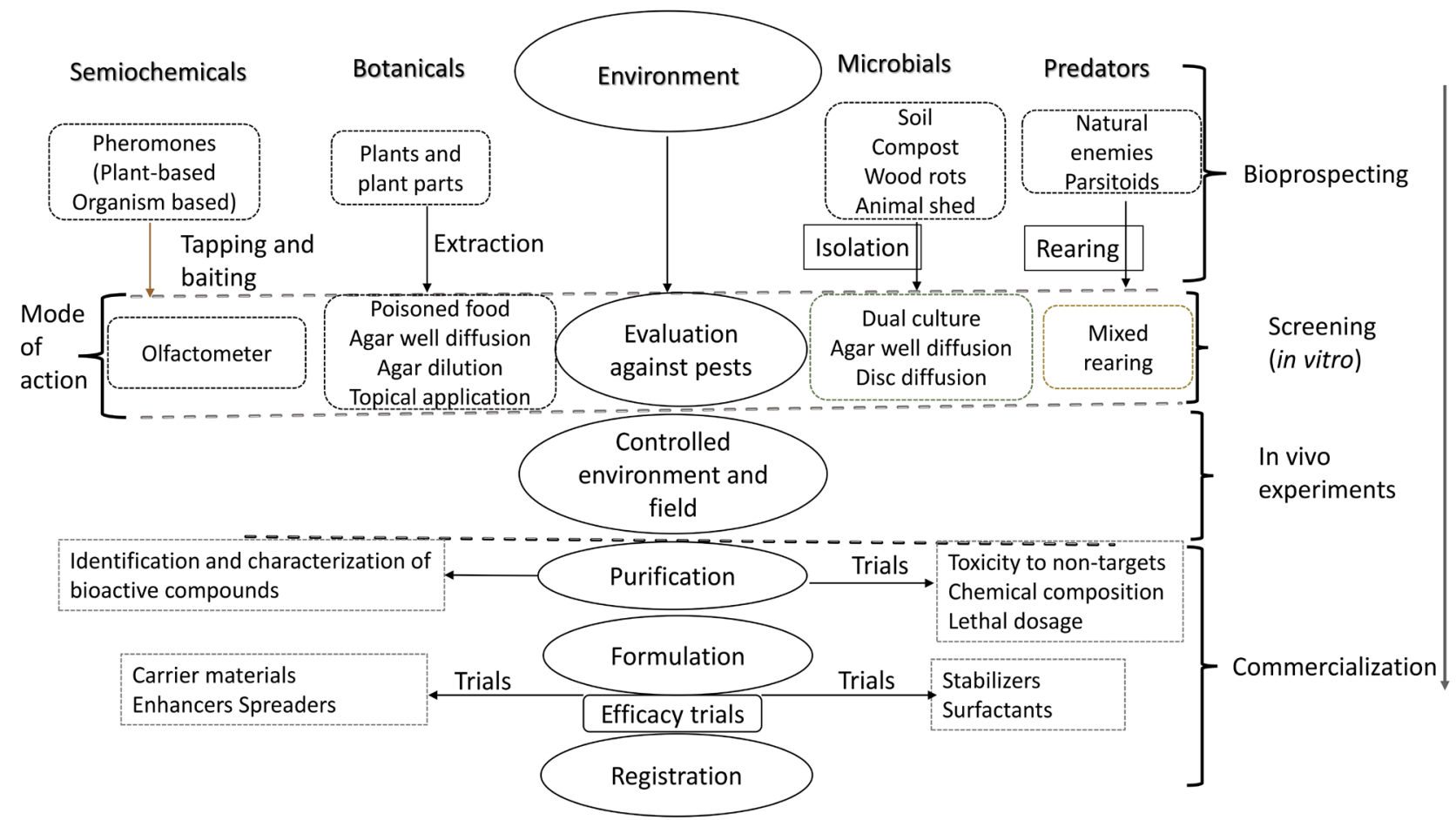

Figure 1. Steps in production and evaluation of different types of biopesticides. 
not lost. Biopesticides of plant origin that have been formulated and commercialized for agricultural use include neem and pyrethrum [209] while microorganisms include species of Bacillus and Trichoderma [210].

\section{Modes of Action of Biopesticides}

Each type of biopesticide exhibits varied modes of action. Microbial pesticides act on pathogens by antagonism, hyperparasitism, antibiosis and predation. Botanical pesticides inhibit growth of pathogens, modify their cellular structures and morphology and exhibit neurotoxicity on insects. Botanicals also repel insects, suppress oviposition and feeding. Predators mainly kill the prey through parasitization or injection of toxic substances which eventually kill the prey. Semiochemicals are used to lure the target pests and they can then be managed through other means such as sterilization or death.

Extracts from plants belonging to Asteraceae family have been reported to inhibit hyphal growth and induce structural modifications on mycelia of plant pathogenic fungi [6]. Asteraceae plants contain compounds such as flavanoids, coumarins alkaloids and terpenoids which could lead to absolute fungal toxicity. Some compounds lead to changes in the cell wall as well as the morphology of celleular organelles [211]. In some instances, the bioactive compounds cause partitioning of fungal cell membranes making them permeable leading to leakage of cell contents. Plant bioactive compounds also lead to separation of the cytoplasmic membrane which leads to damage of the intracellular components and swelling of cells leading to eventual death [212]. Compounds such as allicin found in garlic (Allium sativum) bulbs lead to suffocation of the pest due to effects on receptors of neurotransmitters [77]. Phenolics and terpenoids build hydrophobic and ionic bonds which attack a multiple of proteins in the insects leading to physiological malfunction [213]. Compounds in plant extracts and essential oils also interfere with receptor cells leading to malfunctioning of the nervous system and failure of coordination leading to death of the insect [214].

Different classes of microorganisms have different modes of actions. Hyperparasitism is one of the most reported mode of action on many biocontrol agents [215]. The antagonist kills the pathogen or its propagules while some attack the sclerotia or the hypha of the fungal pathogen. A single pathogen could be attacked by a number of biocontrol agents [216]. Pasteuria penetrans is an example of a biocontrol agent that parasitizes on root-knot nematodes of $\mathrm{Me}$ loidogyne spp. [217]. Species of genus Trichoderma exhibit a predation mode of action by producing enzymes that directly kill cell walls of the pathogens and colonize the environment therein.

Some microorganisms produce compounds that kill other microorganisms, a mechanism called antibiosis. This is most common with bacteria belonging to species of Pseudomonas, Agrobacterium, Bacillus, Burkholderia, Pantoea and it has also been reported in the fungus Trichoderma spp. [218]. Sufficient quantities of antibiotics need to be produced for enhanced biocontrol. Some microbial 
species such as Bacillus cereus produce multiple compounds that could suppress more than two pathogens and this is effective in crop disease management [219]. Other classes of microorganisms such as Lysobacter and Myxobacteria produce lytic enzymes which hydrolyze compounds leading to suppression of pathogens [220]. Beauveria bassiana inhibits chitin development in insects by conidia attaching to the body of insects. After germination the hypha penetrates through the cuticle and grows throughout the insect body eventually killing it [26].

Semicochemicals such as female sex pheromones are used to lure the male insect pests which are then sterilized thereby decreasing their effectiveness. Upon mating with the sterile male insects, the females lay unfertilized eggs thereby reducing harmful insect populations [221]. Host location pheromeones lure insects into sites with mass traps from where they may be sterilized or starved to death [222]. Predators may feed on the prey or a particular life stage of the prey such as nymphs or larvae [187]. The predator prey ratio is of importance in balancing the populations of the pests as well as biodiversity [223].

\section{Efficacy of Different Types of Biopesticides}

Synthetic pesticides are considered more effective than biopesticides in managing crop pests [224]. Their effectiveness sometimes has nonetheless no much significance in managing a particular population of pest as would the biopesticides [225]. Biopesticides in other instances perform better than synthetic pesticides when applied in the right regimes, concetrations and appropriate frequencies [226]. Research reports across the world have presented different plants, microorganisms and predators with potential as biopesticides. Natural enemies predate on insect pests which balances their population in the ecosystem. Such predators are important in agricultural systems [223] [227]. The mechanisms used by predators to lure insects include scents and other attractants. Some of these scents, called pheromones, have been commercialized and are being used in management of important crop pests such as Tuta absoluta [221]. The commercial pheromones are baited to aid in luring the adult insects and then deactivating them by sterilization or startvation to death [228].

Certain plants contain compounds which they use to protect themselves against pests and this ability has been explored by researchers in an effort to manage different crop pests [118]. Some plants have been found to contain compounds that are effective against several pests including fungi and nematodes [229] [230]. Some species of microorganisms have antagonistic properties towards other species and are therefore effective as biopesticides [231].

Ngegba et al., [232] reported that extracts of neem (Azadirachta indica) and Mexican sunflower (Tithonia diversifolia) inhibited growth of rotting disease pathogens of tomato, Aspergillus niger, Fusarium oxysporum and Geotrichum candidium by up to $100 \%$. Extracts of castor seeds (Ricinus communis) effectively inhibited growth of post-harvest pathogens Penicillium oxalicum and Aspergillus niger of yams (Dioscorea alata) in a dose dependent poisoned food 
technique experiment [233]. Similar effects were reported by Devi et al., [234] on post-harvest fungi including Fusarium solani, Rhizopus arrhizus and Sclerotium rolfsii after using extracts from Duranta erecta and Lasonia ineruis. Methanolic extracts of Chenopodium ambrosioides exhibited antifungal activity against $\mathrm{Fu}$ sarium oxysporum f.sp. ciceris a pathogen that causes wilt of chick pea (Cicer arietinum) by up to $50 \%$ [235].

A biopesticide formulation containing onion (Allium cepa) and ginger (Zingiber officinale) was evaluated for efficacy against tomato fruit worm (Helicoverpa armigera) and registered a $70 \%-80 \%$ control [236]. During the study, yield increment was also observed on plants treated with the formulation compared to the untreated controls. Muzemu et al., [237] reported over 50\% reduction of rape aphids (Brevicoryne brassicae) and tomato red spider mites (Tetranychus evansi) by powder extracts of Lippia javanica and Solanum delaguense. Populations of Megalurothrips sjostedti were reduced by extracts of Piper nigrum, Cinnamomum zeylanium and Cinnamomum cassia and were reported to be strong repellents [105]. Number of larvae and pupa of Helicoverpa armigera were effectively reduced by extracts of Curcuma longa, Allium sativum and henge (Ferula assa-foetida) in a study by Shah et al., [226]. Extracts of Artemisia herbaalba, Eucalyptus camaldulensis and Rosmarinus officinalis soaked on leaves of broad bean (Vicia faba) caused a mortality of $60 \%-100 \%$ of green peach aphid (Myzus persicae) after 24 hours of exposure in dose dependent in vitro experiments [238]. In another study, topical application of Azadirachta indica, Mangifera indica, Polyalthia longifolia, Annona squamosa and Ficus benghalensis caused a 100\% mortality of bed bugs (Cimex lectularius) after 19 seconds of contact [239]. The effectiveness of plant extracts on insects is credited to the solvents used and their ability to extract major compounds with insecticidal properties [240] [241].

Bacillus subtilis, Pseudomonas putida and Pseudomonas aeruginosa were evaluated against Fusarium oxysporum f.sp. ciceris and reported to have better control in seed treatment and resulted in an increment in growth parameters [205]. Species of Bacillus have been reported to produce compounds effective against important fungal pathogens including Rhizoctonia solani and Xanthomonas oryzae pv. oryzae [124] [242]. Compounds from Chaetomium globosum have also been reported effective against important fungal pathogens of rice such as Magnaporthe grisea and Puccinia recondita [126]. Anitha and Rabeeth [243], reported reduced severity of fusarium wilt of tomato after using Streptomyces griseus. In a seeded media experiment, Stenotrophomnas maltophilia, Bacillus subtilis and Pseudomonas aeruginosa exhibited antagonism against Erwinina carotovora [244].

A formulation consisting of compost tea extracts and poultry litter reduced severity of bacterial wilt (Ralstonia solanacearum) of brinjals (Solanum melongena) [245]. Higher efficacy was observed when the compost tea extract was applied as a soil drench and the poultry litter applied on the soil which resulted in healthy plants and improved yield. A similar formulation reduced the incidence 
and severity of late blight (Phytophtora infestans) of potato (Solanum tuberosum) when the compost tea was applied as a foliar spray [246]. Research by Pane et al., [247] showed that a compost tea formulation containing wood chips improved yield of lettuce (Lactuca sativa var. gentilina) and Kohlrabi or German turnip (Brassica oleracea var. gongylodes) when applied as a foliar spray.

Semiochemicals have been employed in management of insect pests. As reported by Chermiti and Abbes [222], mass trapping by use of sex pheromones with water traps has been used in management of Tuta absoluta by delaying initial attacks on tomato plants. Similarly, fruit flies (Rhagoletis cingulata) have been managed through semiochemicals such as sex pheromones, oviposition, host location and mating pheromones [248]. According to Powell and Pickett [249], these semiochemicals could be insect-plant induced or insect induced and the end result is enhanced parasitizing of the insect populations.

Predators of insect and microbial nature have been effectively used in management of insect pests. Species of Amblyseius swirskii have been used in the management of thrips, Frankliniella occidentalis and Scirtothrips dorsalis and spider mites (Tetranychus urticae) [187] [193]. Phytoseiulus persimilis is an effective predator mite against spider mites (Tetranyshus spp.) [188]. According to a study by Vá Squez et al., [194], aphid predators (Aphidius colemani) were reported to be effective on Aphis gossypii on crysanthemums (Dendranthema grandiflora).

\section{Why Biopesticides in Sustainable Agricultural Production}

Biopesticides are as effective as synthetic pesticides in management of crop pests [24]. Natural products are also eco-friendly since they are easily biodegradable and therefore do not pollute the environment [250]. Consumer tastes and preferences fluctuate over time and following the demand for organically produced food, this makes biopesticides suitable alternatives to synthetic pesticides [251]. Biopesticides have very short pre-harvest intervals and are therefore safe to use on fresh fruits and vegetables [209]. They are also target specific and hence do not affect the beneficial organisms such as the natural enemies [252]. They are effective in small quantities and their use promotes sustainable pest management and hence contribute towards sustainable agriculture [253].

Natural pesticides do not cause resistance build up among pests [145]. Availability of their source materials makes them inexpensive to attain since they are found within the natural environment and some of them are used for other purposes like food and feed [254]. Biopesticides are safe products both for the applicant and the consumer since they have no toxicity [16]. Therefore, biopesticides can suitably be incorporated in integrated pest management (IPM) which helps reduce the amounts of chemical pesticides used in management of crop pests [255]. Natural products decompose quickly which makes them safer for use in the environment [256]. Pesticides from natural sources have very short re-entry intervals which guarantee safety for the applicant [257]. Biopesticides 
are also used in decontamination of agricultural soils through introduction of important microbial species [258].

\section{Limitations Facing Use of Biopesticides}

While biopesticides provide such advantages as safe environment and healthy food for human consumption, there are factors that limit their full adoption as pest and disease management options. High doses of the constituent compounds are needed for efficacy under field conditions [252]. The concentration of the bioactive compounds in plants is dictated by the environment under which they grow [15]. The constituent active compounds are also dictated by the diversity of plants and their varieties resulting in differences in the responses to pathogens [259]. The quality of botanical extracts is also dependednt on the method of extraction used [255]. During formulation, it is sometimes challenging to get the right proportions of the active and inert ingredients needed. There are also no standard preparation methods and guidelines for efficacy testing especially under field conditions [251]. While the in vitro tests produce excellent results, there are always inconsistencies at the field due to low shelf life and sometimes poor quality of source materials or preparation methods.

Adoption of biopesticides of predatory nature need a lot of consideration such as host crops and dispersal capability [260]. Crop coverage and exposure time are essential and for a small acreage this could prove expensive since application may be manual [261]. Registration of the products requires data on chemistry, toxicity, packaging and formulation which is not always readily available [262]. The cost of producing a new pesticide product is usually high and has a lot of resource limitations [257]. Lack of a readily available market makes it hard to invest in biopesticides [257]. There are insufficient facilities and capital for production of biopesticides especially in the slowly developing countries. The shelf life of natural products is dependent on many factors such as temeperatures and moisture which are sometimes difficult to control [120]. Biopesticides also face high competition from synthetic pesticides and if the former were produced for a small agricultural activity, the costs may be relatively high and therefore not feasible. There is insufficient awareness about biopesticides especially among the small-scale growers, stake holders and policy makers. In the case of microbial pesticides, there is usually no trust in the value and use chain between producers, buyers and users and considering the risk of importation, synthetic pesticides appear reliable [263].

\section{Conclusion and Future Prospects}

Despite the many challenges facing the adoption of biopesticides, they still remain suitable alternatives to conventional pesticides. Use of synthetic chemicals has raised numerous concerns due to their negative effects on the environmental, human health, natural enemies and ecosystem balance. Some of the active ingredients of synthetic pesticides have been found to be carcinogenic thus pos- 
ing a threat to human life. Biopesticides offer better alternative to synthetic pesticides due to their low toxicity, biodegradability and low persistence in the environment. The base materials for biopesticides are readily available and inexpensive. Data on toxicity levels, chemistry, active compounds and their compatibility with other methods of pests and disease management is needed to aid in formulaton and commercialization. Globally, researchers have conducted studies on effectiveness of natural plant protection products with significant results being from in vitro experiments. There are also studies on effectiveness of biopesticides under controlled environments and field conditions with varying results. Further research is recommended to close the gaps in formulation of biopesticides. Stable products under field conditions will be a guarantee of utter effectiveness of biopesticides in crop pest management. Researchers should therefore work together with engineers in the government and industry as well as farmers to provide stable, durable formulations of biopesticides.

\section{References}

[1] Gašić, S. and Tanović, B. (2013) Biopesticide Formulations, Possibility of Application and Future Trends. Journal Pesticides and Phytomedicine (Belgrade), 2, 97-102.

[2] Semeniuc, C.A., Pop, C.R. and Rotar, A.M. (2017) Antibacterial Activity and Interactions of Plant Essential Oil Combinations gainst Gram-Positive and Gram-Negative Bacteria. Journal of Food and Drug Analysis, 25, 403-408.

https://doi.org/10.1016/j.jfda.2016.06.002

[3] Nefzi, A., Abdallah, B.A.R., Jabnoun-Khiareddine, H., Saidiana-Medimagh, S., Haouala, R. and Danmi-Remadi, M. (2016) Antifungal Activity of Aqueous and Organic Extracts from Withania somnifera L. against Fusarium oxysporum f.sp. radicis-lycopersici. Journal of Microbial and Biochemical Technology, 8, 144-150. https://doi.org/10.4172/1948-5948.1000277

[4] Mizubuti, G.S.E., Junior, V.L. and Forbes, G.A. (2007) Management of Late Blight with Alternative Products. Pest Technology, 2, 106-116.

[5] Ali, A.M., Mohamed, D.S., Shaurub, E.H. and Elsayed, A.M. (2017) Antifeedant Activity and Some Biochemical Effects of Garlic and Lemon Essential Oils on Spodoptera littoralis (Boisduval) (Lepidoptera: Noctuidae). Journal of Entomology and Zoology Studies, 3, 1476-1482.

[6] Vidyasagar, G.M. and Tabassum, N. (2013) Antifungal Investigations on Plant Essential Oils: A Review. International Journal of Pharmacy and Pharmaceutical Sciences, 2, 19-28.

[7] Kachhawa, D. (2017) Microorganisms as a Biopesticides. Journal of Entomology and Zoology Studies, 3, 468-473.

[8] Vinale, F., Krishnapillai, S., Ghisalbertic, L.E., Marraa, R., Wooa, L.S. and Loritoa, M. (2008) Trichoderma-Plant-Pathogen Interactions. Soil Biology \& Biochemistry, 40, 1-10. https://doi.org/10.1016/j.soilbio.2007.07.002

[9] Souza, R., Ambrosini, A. and Passaglia, L.M.P. (2015) Plant Growth-Promoting Bacteria as Inoculants in Agricultural Soils. Genetics and Molecular Biology, 4, 401-419. https://doi.org/10.1590/S1415-475738420150053

[10] Abbamondi, G.R., Giuseppina, T., Nele, W., Sofie, T., Wouter, S., Panagiotis, G., Carmine, I., Wesley, M.R., Barbara, N. and Jaco, V. (2016) Plant Growth-Promoting 
Effects of Rhizospheric and Endophytic Bacteria Associated with Different Tomato Cultivars and New Tomato Hybrids. Chemical and Biological Technologies in Agriculture, 1, 1-10.

[11] Compant, S., Clément, C. and Sessitsch, A. (2009) Plant Growth-Promoting Bacteria in the Rhizo- and Endosphere of Plants: Their Role, Colonization, Mechanisms Involved and Prospects for Utilization. Soil Biology \& Biochemistry, 42, 669-678. https://doi.org/10.1016/j.soilbio.2009.11.024

[12] Esitken, A., Yildiz, H.E., Ercisli, S., Donmez, M.F., Turan, M. and Gunes, A. (2009) Effects of Plant Growth Promoting Bacteria (PGPB) on Yield, Growth and Nutrient Contents of Organically Grown Strawberry. Scientia Horticulturae, 124, 62-66. https://doi.org/10.1016/j.scienta.2009.12.012

[13] Knutson, A. and Ruberson, J. (2015) Field Guide to Predators, Parasites and Pathogens Attacking Insect and Mite Pests of Cotton. In: Smith, E.M., Ed., Texas Cooperative Extension, TX Publication, 136.

[14] Wu, K., Lin, K., Miao, J. and Zhang, Y. (2005) Field Abundances of Insect Predators and Insect Pests on $\delta$-Endotoxin-Producing Transgenic Cotton in Northern China. Second International Symposium on Biological Control of Arthropods, Davos, 362-368.

[15] Ghorbani, R., Wilcockson, S. and Leifert, C. (2005) Alternative Treatments for Late Blight Control in Organic Potato: Antagonistic Micro-Organisms and Compost Extracts for Activity against Phytophthora infestans. Potato Research, 48, 181-189. https://doi.org/10.1007/BF02742375

[16] Damalas, C.A. and Koutroubas, S.D. (2015) Farmers' Exposure to Pesticides: Toxicity Types and Ways of Prevention. Toxics, 1, 1-10.

[17] Kekuda, P.T.R., Akarsh, S., Nawaz, S.A.N., Ranjitha, M.C., Darshini, S.M. and Vidya, P. (2016) In Vitro Antifungal Activity of Some Plants against Bipolaris sarokiniana (Sacc.) Shoem. International Journal of Current Microbiology and Applied Sciences, 6, 331-337. https://doi.org/10.20546/ijcmas.2016.506.037

[18] Parliman, D.J. (2001) Soil Analyses for 1,3-Dichloropropene (1,3-DCP), Sodium N-Methyldithiocarbamate (Metam-Sodium), and Their Degradation Products near Fort Hall, Idaho, September 1999 through March 2000. Water-Resources Investigations Report 01-4052. https://pubs.usgs.gov/wri/2001/4052/report.pdf.

[19] PAN (2011).

https://www.pan-europe.info/old/Resources/Reports/PAN-report\%20on\%20essenti al\%20use\%20of\%20Metam.pdf

[20] Morrissey, W.A. (2006) Methyl Bromide and Stratospheric Ozone Depletion. CRS Report for Congress, 1-6.

[21] Kumari, A., Kumar, K. N. R. and Rao, C. H. N., (2014) Adverse Effects of Chemical Fertilizers and Pesticides on Human Health and Environment. Proceedings National Seminar on Impact of Toxic Metals, Minerals and Solvents leading to Environmental Pollution. Journal of Chemical and Pharmaceutical Sciences, 3, 150-151.

[22] Maksymiv, I. (2015) Pesticides: Benefits and Hazards. Journal of Vasyl Stefanyk Precarpathian National University, 1, 70-76. https://doi.org/10.15330/jpnu.2.1.70-76

[23] Harada, T., Takeda, M., Kojima, S. and Tomiyama, N. (2016) Toxicity and Carcinogenicity of Dichlorodiphenyltrichloroethane (DDT). Toxicological Research, $32,21$.

[24] Birech, R., Bernhard, F. and Joseph, M. (2006) Towards Reducing Synthetic Pesticides Imports in Favour of Locally Available Botanicals in Kenya. Proceedings International Agricultural Research for Development, Bonn, 8-12. 
[25] Halimatunsadiah, A.B., Norida, M., Omar, D. and Kamarulzaman, N.H. (2016) Application of Pesticide in Pest Management: The Case of Lowland Vegetable Growers. International Food Research Journal, 1, 85-94.

[26] Prasad, A. and Syed, N. (2010) Evaluating Prospects of Fungal Biopesticide Beauveria bassiana (Balsamo) against Helicoverpa armigera (Hubner): An Eco-Safe Strategy for Pesticidal Pollution. Asian Journal of Experimental Biological Sciences, 3, 596-601.

[27] Ndakidemi, B., Mtei, K. and Ndakidemi, P.A. (2016) Impacts of Synthetic and Botanical Pesticides on Beneficial Insects. Agricultural Sciences, 7, 364-372. https://doi.org/10.4236/as.2016.76038

[28] Jantasorn, A., Moungsrimuangdee, B. and Dethoup, T. (2016) In Vitro Antifungal Activity Evaluation of Five Plant Extracts against Five Plant Pathogenic Fungi Causing Rice and Economic Crop Diseases. Journal of Biopesticides, 1, 1-7.

[29] Ghorab, M.A. and Khalil, M.S. (2015) Toxicological Effects of Organophosphates Pesticides. International Journal of Environmental Monitoring and Analysis, 4, 218-220. https://doi.org/10.11648/j.ijema.20150304.13

[30] Dey, K.R., Choudhury, P. and Dutta, B.K. (2015) Impact of Pesticide Use on the Health of Farmers: A study in Barak Valley, Assam (India). Journal of Environmental Chemistry and Ecotoxicology, 10, 269-277.

[31] Alavanja, M.C.R., Ross, M.K. and Bonner, M.R. (2013) Increased Cancer Burden among Pesticide Applicators and others Due to Pesticide Exposure. A Cancer Journal for Clinicians, 63, 120-142. https://doi.org/10.3322/caac.21170

[32] Xavier, G., Chandran, M., Naseema, B.S., Mathew, T.B., George, T., Vijayasree, V., Pratheeshkumar, N. and Kumar, S.V. (2016) Persistence of Fenpyroximate in Chilli Pepper (Capsicum annum L.) and Soil and Effect of Processing on Reduction of Residues. Pesticide Research Journal, 2, 145-151.

[33] Pandey, S., Gill, R.S. and Mandal, K. (2016) Persistence and Efficacy of Spinosad, Indoxacarb and Deltamethrin against Major Insect Pests of Stored Wheat. Pesticide Research Journal, 28, 178-184.

[34] Business Daily (2014) Regulator Suspends Use of Pesticides on Vegetables. 13 October 2014.

[35] Business Daily (2013) Chemical Ban Hits Vegetable Exports to the EU Market. 14 February 2013.

[36] European Commission (2012) Amending Annex I to Regulation (EC) No 669/2009 Implementing Regulation (EC) No 882/2004 of the European Parliament and of the Council as Regards the Increased Level of Official Controls on Imports of Certain Feed and Food of Non-animal Origin. Official Journal of the European Union. L. $350 / 44.20 / 12 / 2012$.

[37] Business Daily (2014) Illegal Horticulture Exports Risk Kenya’s EU Market. 26 May 2014.

[38] Daily Nation (2014) Bio-Pesticides in Focus as Safety Concerns Reshape Export Trade. 7 June 2014.

[39] Daily Nation (2016) Boost for Horticulture as New System Set to Improve Quality. 9 September 2016.

[40] Chougule, P.M. and Andoji, Y.S. (2016) Antifungal Activity of Some Common Medicinal Plant Extracts against Soil Borne Phytopathogenic Fungi Fusarium oxysporum Causing Wilt of Tomato. International Journal of Development Research, 3, 7030-7033. 
[41] Zarubova, L., Lenka, K., Pavel, N., Miloslav, Z., Ondrej, D. and Skuhrovec, J. (2014) Botanical Pesticides and Their Human Health Safety on the Example of Citrus sinensis Essential Oil and Oulema melanopus under Laboratory Conditions. Mendel Net, 330-336.

[42] Muthomi, J.W., Lengai, G.M.W., Wagacha, J.M. and Narla, R.D. (2017) In Vitro Activity of Plant Extracts against Some Important Plant Pathogenic Fungi of Tomato. Australian Journal of Crop Science, 6, 683-689. https://doi.org/10.21475/ajcs.17.11.06.p399

[43] Baştaş, K.K. (2015) Determination of Antibacterial Efficacies of Plant Extracts on Tomato Bacterial Speck Disease. Journal of Turkish Phytopathology, 1-3, 1-10.

[44] Salim, H.A., Salman, I.S., Ishtar, I.M. and Hatam, H.H. (2016) Evaluation of Some Plant Extracts for their Nematicidal Properties against Root-Knot Nematode, $\mathrm{Me}$ loidogyne sp. Journal of Genetic and Environmental Resources Conservation, 3, 241-244.

[45] Dar, A.S., Nisar, A.D., Mudasir, A.B. and Mudasir, H.B. (2014) Prospects, Utilization and Challenges of Botanical Pesticides in Sustainable Agriculture. International Journal of Molecular Biology \& Biochemistry, 1, 1-14.

[46] Odhiambo, A.J., Siboe, G.M., Lukhoba, C.W. and Dossaji, F.S. (2009) Antifungal Activity of Crude Extracts of Selected Medicinal Plants Used in Combination in Lake Victoria Basin, Kenya. Plant Product Research Journal, 13, 35-43.

[47] Javaid, A. and Rehman, A.H. (2011) Antifungal Activity of Leaf Extracts of Some Medicinal Trees against Macrophomina phaseolina. Journal of Medical Plants Research, 13, 2858-2872.

[48] Bandor, H., Hijazi, A., Rammal, H., Hachem, A., Saad, Z. and Badran, B. (2013) Techniques for the Extraction of Bioactive Compounds from Labanese Urtica diotica. American Journal of Phytomedicine and Clinical Therapeutics, 6, 507-513.

[49] Mahlo, S.M., Chauk, H.R., McGaw, L.J. and Eloff, J.N. (2013) Antioxidant and Antifungal Activity of Selected Plant Species Used in Traditional Medicine. Journal of medical Plants Research, 33, 2444-2450.

[50] Wetungu, M.W., Matasyoh, J.C. and Kinyanjui, T. (2014) Antimicrobial Activity of Solvent Extracts from the Leaves of Tarchonanthus camphoratus (Asteraceae). Journal of Pharmacognosy and Phytochemistry, 1, 123-127.

[51] Sunder, J., Singh, D.R., Jeyakumar, S., Kundu, A. and Kumar, A. (2011) Antibacterial Activity in Solvent Extract of Different Parts of Morinda citrifolia plant. Journal of Pharmaceutical Sciences and Research, 8, 1404-1407.

[52] Ahmad, A., Alkarkhi, A.F.M., Hena, S. and Lim, H.K. (2009) Extraction, Separation and Identification of Chemical Ingredients of Elephantopus scaber L. Using Factorial Design of Experiment. International Journal of Chemistry, 1, 36-49. https://doi.org/10.5539/ijc.v1n1p36

[53] Baidoo, P.K., Baidoe-Ansah, D. and Agbonu, I. (2012) Effects of Neem (Azadirachta indica A. Juss) Products on Aphis craccivora and its Predator Harmonia axyridis on Cowpea. American Journal of Experimental Agriculture, 2, 198-206. https://doi.org/10.9734/AJEA/2012/928

[54] Vinodhini, J. and Malaikozhundan, B. (2011) Efficacy of Neem and Pungam Based Botanical Pesticides on Sucking Pests of Cotton. Indian Journal of Agricultural Research, 4, 341-345.

[55] Déla, M.A., Koffivi, K.G., Komina, A., Arnaud, A., Phillipe, G. and Adole, I.G. (2014) Evaluation of Neem Leaves-Based Preparation as Insecticidal Agents against 
the Green Peach Aphid, Myzus persicae (Sternorrhyncha: Aphididae). African Journal of Agricultural Research, 17, 1344-1352.

[56] Aziz, M.A., Ahmad, M., Nasir, M.F. and Naeem, M. (2013) Efficacy of Different Neem (Azadirachta indica) Products in Comparison with Imidacloprid against English Grain Aphid (Sitobionavenae) on Wheat. International Journal of Agriculture \& Biology, 2, 279-284.

[57] Biswas, G.C. (2013) Comparative Effectiveness of Neem Extracts and Synthetic Organic Insecticide against Mustard Aphid. Bangladesh Journal of Agricultural Research, 2, 181-187. https://doi.org/10.3329/bjar.v38i2.15881

[58] Mondali, N.K., Mojumdar, A., Chatterje, S.K., Banerjee, A., Datta, J.K. and Gupta, S. (2009) Antifungal Activities and Chemical Characterization of Neem Leaf Extracts on the Growth of some Selected Fungal Species in Vitro Culture Medium. Journal of Applied Sciences and Environmental Management, 1, 49-53.

[59] Wang, J., Li, J., Cao, J. and Jiang, W. (2010) Antifungal Activities of Neem (Azadirachta indica) Seed Kernel Extracts on Postharvest Diseases in Fruits. African Journal of Microbiology Research, 11, 1100-1104.

[60] Al-Hazmi, R.H.M. (2013) Effect of Neem (Azadirachta indica) Leaves and Seeds Extract on the Growth of Six of the Plant Disease Causing Fungi. Global Advanced Research Journal of Microbiology, 5, 89-98.

[61] Raut, R.R., Sawant, A.R. and Jamge, B.B. (2014) Antimicrobial Activity of Azadirachta indica (Neem) against Pathogenic Microorganisms. Journal of Academia and Industrial Research, 7, 327-329.

[62] Javed, N., Anwar, S.A., Fyaz, S., Khan, M.M. and Ashfaq, M. (2008) Effects of Neem Formulations Applied as Soil Drenching on the Development of Root-Knot Nematode Meloidogyne javanica on Roots of Tomato. Pakistan Journal of Botany, 2, 905-910.

[63] Kumar, S. and Khanna, A.S. (2006) Effect of Neem-Based Products on the Root-Knot Nematode, Meloidogyne incognita, and Growth of Tomato. Nematologia Mediterranea, 34, 141-146.

[64] Castillo-Sánchez, L.E., Jiménez-Osornio, J.J., Delgado-Herrera, M.A., Candelaria-Martínez, B. and Sandoval-Gío, J.J. (2015) Effects of the Hexanic Extract of Neem Azadirachta indica against Adult Whitefly Bemisia tabaci. Journal of Entomology and Zoology Studies, 5, 95-99.

[65] Stanley, J., Preetha, G., Chandrasekaran, S., Gunasekaran, K. and Kuttalam, S. (2014) Efficacy of Neem Oil on Cardamom Thrips, Sciothrips cardamomi Ramk, and Organoleptic Studies. Psyche, 2014, Article ID: 930584. https://doi.org/10.1155/2014/930584

[66] Suleiman, E.A. and Abdallah, W.B. (2014) In Vitro Activity of Garlic (Allium sativum) on Some Pathogenic Fungi. European Journal of Medicinal Plants, 10, 1240-1250. https://doi.org/10.9734/EJMP/2014/10132

[67] Aala, F., Yusuf, U.K., Nulit, R. and Rezaie, S. (2014) Inhibitory Effect of Allicin and Garlic Extracts on Growth of Cultured Hyphae. Iranian Journal of Basic Medical Sciences, 17, 150-154.

[68] Perelló, A., Noll, U. and Slusarenko, A.J. (2013) In Vitro Efficacy of Garlic Extract to Control Fungal Pathogens of Wheat. Journal of Medicinal Plants Research, 24, 1809-1817.

[69] Tawfik, M.M., Sami, R.A. and Eman, T.A. (2000) Effect of Garlic Bulb Extract on the Growth and Enzymatic Activities of Rhizosphere and Rhizoplane Fungi. Myco- 
pathologia, 152, 143-146. https://doi.org/10.1023/A:1013184613159

[70] Alam, S., Han, K.D., Lee, J.M., Hur, H., Shim, J., Chang, K., Lee, T. and Lee, M.W. (2004) In Vitro Effects of Plant Extracts and Phytohormones on Mycelial Growth of Anthracnose Fungi. Mycobiology, 3, 134-138. https://doi.org/10.4489/MYCO.2004.32.3.134

[71] Durairaj, S., Srinivasan, S. and Lakshmanaperumalsamy, P. (2009) In Vitro Antibacterial Activity and Stability of Garlic Extract at Different $\mathrm{pH}$ and Temperature. Electronic Journal of Biology, 1, 5-10.

[72] Khalegi, M., Eshlaghi, B.S. and Ghotaslou, R. (2016) Antibacterial Effects of Azerbaijan Garlic (Allium sativum). Short Communication. Journal of Zoonotic Diseases, 1, 30-34.

[73] Strika, I., Bašić, A. and Halilović, N. (2016) Antimicrobial Effects of Garlic (Allium sativum L.). Bulletin of the Chemists and Technologists of Bosnia and Herzegovina, 47, 17-20.

[74] Yang, F., Zhu, F. and Lei, C. (2012) Insecticidal Activities of Garlic Substances against Adults of Grain Moth, Sitotroga cerealella (Lepidoptera: Gelechiidae). Insect Science, 19, 205-212. https://doi.org/10.1111/j.1744-7917.2011.01446.x

[75] Plata-Rueda, A., Martínez, L.C., Santos, M.H., Fernandes, F.L., Wilcken, C.F., Soares, M.A., Serrão, J.E. and Zanuncio, J.C. (2017) Insecticidal Activity of Garlic Essential Oil and Their Constituents against the Mealworm Beetle, Tenebrio molitor Linnaeus (Coleoptera: Tenebrionidae). Scientific Reports, 7, 46406. https://doi.org/10.1038/srep46406

[76] Tiroesele, B., Thomas, K. and Seketeme, S. (2015) Control of Cowpea Weevil, Callosobruchus maculatus (F.) (Coleoptera: Bruchidae), Using Natural Plant Products. Insects, 6, 77-84. https://doi.org/10.3390/insects6010077

[77] Baidoo, P.K. and Mochiah, M.B. (2016) Comparing the Effectiveness of Garlic (Allium sativum L.) and Hot Pepper (Capsicum frutescens L.) in the Management of the Major Pests of Cabbage Brassica oleracea (L.). Sustainable Agriculture Research, 2, 83-91. https://doi.org/10.5539/sar.v5n2p83

[78] Voukeng, I.K., Beng, V.P. and Kuete, V. (2017) Multidrug Resistant Bacteria Are Sensitive to Euphorbia prostrata and Six Others Cameroonian Medicinal Plants Extracts. BMC Research Notes, 10, 321. https://doi.org/10.1186/s13104-017-2665-y

[79] Mohammadi, S., Shandiz, S.A.S., Bigdeli, R., Mahboubi, A., Hedayati, M. and Asgary, V. (2016) Evaluation of Anti-Bacterial Properties of Euphorbia CondylocarpaMethanol Extract. Archives of Microbiology and Immunology, 1, 12-20. https://doi.org/10.26502/ami.9365002

[80] Abubakar, E.M. (2009) Antibacterial Activity of Crude Extracts of Euphorbia hirta against Some Bacteria Associated with Enteric Infections. Journal of Medicinal Plants Research, 7, 498-505.

[81] Gayathri, A. and Ramesh, K.V. (2013) Antifungal Activity of Euphorbia hirta L. Inflorescence Extract against Aspergillus flavus-A Mode of Action Study. International Journal of Current Microbiology and Applied Sciences, 4, 31-37.

[82] Ali, S., Sagheer, M., Hassan, M., Abbas, M., Hafeez, F., Farooq, M., Hussain, D., Saleem, M. and Ghaffar, A.B. (2014) Insecticidal Activity of Turmeric (Curcuma longa) and Garlic (Allium sativum) Extracts against Red Flour Beetle, Tribolium castaneum: A Safe Alternative to Insecticides in Stored Commodities. Journal of Entomology and Zoology Studies, 3, 201-205.

[83] Siddiqi, A.R., Rafi, A., Naz, F., Masih, R., Ahmad, I. and Jilani, G. (2011) Effects of Curcuma longa Extracts on Mortality and Fecundity of Bactrocera zonata (Diptera: 
Tephritidae). Ciênciae Agrotecnologia, 6, 1110-1114. https://doi.org/10.1590/S1413-70542011000600010

[84] Tavares, W.S., Akhtar, Y., Gonçalves, G.L.P., Zanuncio, J.C. and Isman, M.B. (2016) Turmeric Powder and Its Derivatives from Curcuma longa Rhizomes: Insecticidal Effects on Cabbage Looper and the Role of Synergists. Scientific Reports, 6, 34093. https://doi.org/10.1038/srep34093

[85] Mohammed, N.A. and Habi, N.Y. (2015) Evaluation of Antimicrobial Activity of Curcumin against Two Oral Bacteria. Automation, Control and Intelligent Systems, 2, 18-21. https://doi.org/10.11648/j.acis.s.2015030201.14

[86] Murthy, N.K., Soumya, K. and Srinivas, K.C. (2015) Antibacterial Activity of Curcuma longa (Turmeric) Plant Extracts against Bacterial Wilt of Tomato Caused by Ralstoniasolanacearum. International Journal of Science and Research, 1, 2136-2141.

[87] Rawat, S. and Rawat, A. (2015) Antimicrobial Activity of Indian Spices against Pathogenic Bacteria. Advances in Applied Science Research, 3, 185-190.

[88] Altunatmaz, S.S., Aksu, F.Y., Issa, G., Kahraman, B.B., Altiner, D.D. and Buyukunal, S.K. (2016) Antimicrobial Effects of Curcumin against L. monocytogenes, S. aureus, S. Typhimurium and E. coli O157:H7 Pathogens in Minced Meat. Veterinarni Medicina, 5, 256-262. https://doi.org/10.17221/8880-VETMED

[89] Naz, S., Jabeen, S., Ilyas, S., Manzoor, F., Aslam, F. and Ali, A. (2010) Antibacterial Activity of Curcuma longa Varieties against Different Strains of Bacteria. Pakistan Journal of Botany, 1, 455-462.

[90] Riaz, T., Khan, S.N. and Javaid, A. (2008) Antifungal Activity of Plant Extracts against Fusariumoxysporum-The Cause of Corm-Rot Disease of Gladiolus. Mycopath, 1\&2, 13-15.

[91] Granja, E.M., Benitez, S.R. and Sanjuanello, D. (2014) Effect of Antagonists and Plant Extracts in the Control of Protea Wilt (F. oxysporum). American Journal of Plant Sciences, 5, 3203-3212. https://doi.org/10.4236/ajps.2014.521336

[92] Bissa, S. and Bohra, A. (2011) Antibacterial Potential of Pot Marigold. Journal of Microbiology and Antimicrobials, 3, 51-54.

[93] Jankowska, B., Poniedziałek, M. and Jędrszczyk, E. (2009) Effect of Intercropping White Cabbage with French Marigold (Tagetes patula Nana L.) and Pot Marigold (Calendula officinalis L.) on the Colonization of Plants by Pest Insects. Folia Horticulturae, 95-103.

[94] Ploeg, A.T. (2002) Effects of Selected Marigold Varieties on Root-Knot Nematodes and Tomato and Melon Yields. The American Phytopathological Society, 5, 505-508. https://doi.org/10.1094/PDIS.2002.86.5.505

[95] Nikkhah, M., Hashemi, M., Mohammad, B., Habibi, N. and Farhoosh, R. (2017) Synergistic Effects of Some Essential Oils against Fungal Spoilage on Pear Fruit. International Journal of Food Microbiology, 257, 285-294. https://doi.org/10.1016/j.ijfoodmicro.2017.06.021

[96] Shirurkar, D.D. and Wahegaonkar, N.K. (2012) Antifungal Activity of Selected Plant Derived Oils and Some Fungicides Against Seed Borne Fungi of Maize. European Journal of Experimental Biology, 5, 1693-1696.

[97] Zhang, Y., Liu, X., Wang, Y., Jiang, P. and Quek, Y.S. (2015) Antibacterial Activity and Mechanism of Cinnamon Essential Oil against Escherichia coli and Staphylococcus aureus. Food Control, 59, 282-289. https://doi.org/10.1016/j.foodcont.2015.05.032

[98] Lu, F., Ding, Y.C., Ye, X.Q. and Ding, Y.T. (2011) Antibacterial Effect of Cinnamon 
Oil Combined with Thyme or Clove Oil. Agricultural Sciences in China, 9, 1482-1487.

[99] Kong, Y., Lee, S., Moon, Y., Lee, S. and Ahn, Y. (2007) Nematicidal Activity of Cassia and Cinnamon Oil Compounds and Related Compounds toward Bursaphelenchus xylophilus (Nematoda: Parasitaphelenchidae). Journal of Nematology, 39, 31-36.

[100] Witkowska, D., Sowińska, J., Żebrowska, J.P. and Mituniewicz, E. (2016) The Antifungal Properties of Peppermint and Thyme Essential Oils Misted in Broiler Houses. Brazilian Journal of Poultry Science, 4, 629-638.

[101] Moghtader, M. (2012) Antifungal Effects of the Essential Oil from Thymus vulgaris L. and Comparison with Synthetic Thymol on Aspergillus niger. Journal of Yeast and Fungal Research, 6, 83-88.

[102] Karaca, G., Bilginturan, M. and Olgunsoy, P. (2017) Effects of Some Plant Essential Oils against Fungi on Wheat Seeds. Indian Journal of Pharmaceutical Education and Research, 3, S385-S388. https://doi.org/10.5530/ijper.51.3s.53

[103] Lucas, G.C., Alves, E., Pereira, R.B., José Perina, F. and Magela de Souza, R. (2012) Antibacterial Activity of Essential Oils on Xanthomonas vesicatoria and Control of Bacterial Spot in Tomato. Pesquisa Agropecuária Brasileira, 3, 351-359.

https://doi.org/10.1590/S0100-204X2012000300006

[104] Mann, R.S., Tiwari, S., Smoot, J.M., Rouseff, R.L. and Stelinski, L.L. (2012) Repellency and Toxicity of Plant-Based Essential Oils and Their Constituents against Diaphorina citri Kuwayama (Hemiptera: Psyllidae). Journal of Applied Entomology, 136, 87-96. https://doi.org/10.1111/j.1439-0418.2010.01592.x

[105] Abtew, A., Subramanian, S., Cheseto, X., Kreiter, S., Garzia, G.T. and Martin, T. (2015) Repellency of Plant Extracts against the Legume Flower Thrips Megalurothrips sjostedti (Thysanoptera: Thripidae). Insects, 6, 608-625. https://doi.org/10.3390/insects6030608

[106] Cetintas, R. and Yarba, M.M. (2010) Nematicidal Activity of Five Plant Essential Oils on the Southern Root-knot Nematode, Meloidogyne incognita Race 2. Journal of Animal and veterinary Advances, 2, 222-225.

[107] Rodríguez-Kábana, R. and Simmons, L. (2005) Fungicidal, Herbicidal, and Nematicidal Activities of Essential Oils in Slow-Release Formulations. Abstracts XXVII Annual Meeting of ONTA, Viña del Mar, Chile.

[108] Habou, Z.A., Haougui, A., Mergeai, G., Haubruge, E., Toudou, A. and Verheggen, F.J. (2011) Insecticidal Effect of Jatropha curcasOil on the Aphid Aphis fabae (Hemiptera: Aphididae) and on the Main Insect Pests Associated with Cowpeas (Vigna unguiculata) in Niger. Tropicultura, 4, 225-229.

[109] Silva, G.N., Faroni, L.R.A., Sousa, A.H. and Freitas, R.S. (2012) Bioactivity of Jatropha curcas L. to Insect Pests of Stored Products. Journal of Stored Products Research, 48, 111-113. https://doi.org/10.1016/j.jspr.2011.10.009

[110] Srivastava, S., Kumar, R. and Sinha, A. (2012) Antifungal Activity of Jatropha carcus Oil against Some Seed-Borne Fungi. Plant Pathology Journal, 4, 120-123. https://doi.org/10.3923/ppj.2012.120.123

[111] Rampadarath, S., Puchooa, D. and Jeewon, R. (2016) Jatropha curcas L: Phytochemical, Antimicrobial and Larvicidal Properties. Asian Pacific Journal of Tropical Biomedicine, 10, 858-865. https://doi.org/10.1016/j.apjtb.2016.01.019

[112] Asif, M., Parihar, K., Rehman, B., Ganai, M.A., Usman, A. and Siddiqui, M.A. (2013) Bio-Efficacy of Some Leaf Extracts on the Inhibition of Egg Hatching and Mortality of Meloidogyne incognita. Archives of Phytopathology and Plant Protec- 
tion, 8, 1015-1021.

[113] Neeraj, G.S., Kumar, A., Ram, S. and Kumar, V. (2017) Evaluation of Nematicidal Activity of Ethanolic Extracts of Medicinal Plants to Meloidogyne incognita (Kofoid and White) Chitwood Under Lab Conditions. International Journal of Pure and Applied Bioscience, 5, 827-831. https://doi.org/10.18782/2320-7051.2525

[114] Al-Rahmah, A.N., Mostafa, A.A., Abdel-Megeed, A., Yakout, S.M. and Hussein, S.A. (2013) Fungicidal Activities of Certain Methanolic Plant Extracts against Tomato Phytopathogenic Fungi. African Journal of Microbiology Research, 6, 517-524.

[115] Silva, F.C., Chalfoun, S.M., Siqueira, V.M., Botelho, D.M.S., Lima, N. and Batista, L.R. (2011) Evaluation of Antifungal Activity of Essential Oils against Potentially Mycotoxigenic Aspergillus flavus and Aspergillus parasiticus. Brazilian Journal of Pharmacognosy, 5, 1002-1010.

[116] Ekwenye, U.N. and Elegalam, N.N. (2005) Antibacterial Activity of Ginger (Zingiber officinale Roscoe) and Garlic (Allium sativum L.) Extracts on Escherichia coli and Salmonella typhi. International Journal of Molecular Medicine and Advance Science, 1, 411-416.

[117] Abid, R. and Butt, S. (2015) Repellent Activity of Cardamom, Ginger and Nutmeg against Certain Insect Pests. International Journal of Zoology and Research, 6, 1-6.

[118] Rizvi, S.A.H., Hussain, S., Rehman, U.S., Jaffar, S. and Rehman, M.F.U. (2016) Efficacy of Ecofriendly Botanical Extracts of Ginger (Zingiber officinale), Garlic ( $A l$ lium sativum) and Tobacco (Nicotiana tabacum L.) for the Control of Cabbage Looper (Trichoplusiabinotalis) under Agro Ecological Conditions of Peshawar. Pakistan. Journal of Entomology and Zoology Studies, 1, 88-90.

[119] Ayeloja, A.A. and George, F.O.A. (2016) Insecticidal Effects of Natural Preservatives on Insect Pests of Smoked African Mud Catfish, Clarias gariepinus (Burchell, 1822). Journal of Food Processing \& Technology, 12, 1-5.

[120] Koul, O. (2011) Microbial Biopesticides: Opportunities and Challenges. CAB Reviews: Perspectives in Agriculture, Veterinary Science, Nutrition and Natural Resources, 6, 056. http://www.cabi.org/cabreviews

[121] Singh, H.B. (2014) Management of Plant Pathogens with Microorganisms. Proceedings of the Indian National Science Academy, 2, 443-454.

https://doi.org/10.16943/ptinsa/2014/v80i2/55120

[122] Suprapta, D.N. (2012) Potential of Microbial Antagonists as Biocontrol Agents against Plant Fungal Pathogens. International Society for Southeast Asian Agricultural Sciences Journal, 2, 1-8.

[123] Song, C.H., Islam, R.M.D., Jeong, Y.T. and Lee, Y.S. (2012) Isolation and Identification of Antifungal Compounds from Bacillus subtilis c9 Inhibiting the Growth of Plant Pathogenic Fungi. Mycobiology, 1, 59-66.

[124] Beric, T., Koji, M., Stankovi, S., Topisirovi, L., Degrassi, G., Myers, M., Venturi, V. and Fira, D. (2012) Antimicrobial Activity of Bacillus sp. Natural Isolates and their Potential use in the Biocontrol of Phytopathogenic Bacteria. Food Technology and Biotechnology, 1, 25-31.

[125] Adan, M.J., Baque, M.A., Rahman, M.M., Islam, M. and Jahan, A. (2015) Formulation of Trichoderma Based Biopesticide for Controlling Damping off Pathogen of Eggplant Seedling. Universal Journal of Agricultural Research, 3, 106-113.

[126] Park, J. P., Gyung, J. C., Kyoung, S. J., He, K. L., Heung, T. K., Kwang, Y. C. and Kim, J. C. (2005) Antifungal Activity against Plant Pathogenic Fungi of Chaetoviridins Isolated from Chaetomium globosum. FEMS Microbiology Letters, 252, 309-313. https://doi.org/10.1016/j.femsle.2005.09.013 
[127] El-Katatny, M.H., El-Katatny, M.S., Fadl-Allah, M.E. and Emam, A.S. (2011) Antagonistic Effect of Two Isolates of Trichoderma harzianum against Postharvest $\mathrm{Pa}$ thogens of Tomato (Lycopersiconesculentum). Archives of Phytopathology and Plant Protection, 7, 637-654. https://doi.org/10.1080/03235400903266438

[128] Al-Naemi, F.A., Ahmed, T.A., Nishad, R. and Radwan, O. (2016) Antagonistic Effects of Trichoderma harzianumIsolates against Ceratocystis radicicola: Pioneering a Biocontrol Strategy against Black Scorch Disease in Date Palm Trees. Journal of Phytopathology, 7-8, 464-475. https://doi.org/10.1111/jph.12472

[129] Al-Saeedi, S.S. and Al-Ani, B.M. (2014) Study of Antagonistic Capability of Trichoderma harzianum Isolates against some Pathogenic Soil Borne Fungi. Agriculture and Biology Journal of North America, 1, 15-23.

[130] Ghanbarzadeh, B., Safaie, N. and Goltapeh, E.M. (2014) Antagonistic Activity and Hyphal Interactions of Trichoderma spp. against Fusarium proliferatum and F. oxysporum in Vitro. Archives of Phytopathology and Plant Protection, 16, 1979-1987. https://doi.org/10.1080/03235408.2013.864506

[131] Talla, G.S., Raju, A.S.R., Karri, S. and Kumar, S.Y. (2015) Production and Antagonistic Effect of Trichoderma spp on Pathogenic Microorganisms (Botrytis cinerea, Fusarium oxysporum, Macrophomina phaseolina and Rhizoctonia solani). African Journal of Biotechnology, 8, 668-675.

[132] Küçük, C. (2017) In Vitro Antagonistic Activity against Fusarium Species of Local Trichoderma spp. Isolates. Journal of Biodiversity and Environmental Sciences, 32, 67-74.

[133] Fatima, K., Noureddine, K., Henni, J.E. and Mabrouk, K. (2015) Antagonistic Effect of Trichodermaharzianum against Phytophthora infestans in the North-West of Algeria. International Journal of Agronomy and Agricultural Research, 4, 44-53.

[134] Jiang, H., Zhang, L., Zhang, J., Ojaghian, M.R. and Hyde, K.D. (2016) Antagonistic Interaction between Trichoderma asperellum and Phytophthora capsici in Vitro. Journal of Zhejiang University-Science B (Biomedicine \& Biotechnology), 4, 271-281. https://doi.org/10.1631/jzus.B1500243

[135] Singh, S. and Mathur, N. (2010) In Vitro Studies of Antagonistic Fungi against the Root-knot Nematode, Meloidogyne incognita. Biocontrol Science and Technology, 3, 275-282. https://doi.org/10.1080/09583150903484318

[136] Javeed, M.T., Al-Hazmi, A.S. and Molan, Y.Y. (2016) Antagonistic Effects of Some Indigenous Isolates of Trichoderma spp. against Meloidogyne javanica. Pakistan Journal of Nematology, 2, 183-191.

[137] Fan, J., Xie, Y., Xue, J. and Liu, R. (2013) The Effect of Beauveria brongniartii and Its Secondary Metabolites on the Detoxification Enzymes of the Pine Caterpillar, Dendrolimus tabulaeformis. Journal of Insect Science, 44, 1-13. https://doi.org/10.1673/031.013.4401

[138] Mohan, M.C., Reddy, N.P., Devi, U.K., Kongara, R. and Sharma, H.C. (2007) Growth and Insect Assays of Beauveria bassiana with Neem to Test their Compatibility and Synergism. Biocontrol Science and Technology, 10, 1059-1069. https://doi.org/10.1080/09583150701714551

[139] Mohammadbeigi, A. and Port, G. (2015) Effect of Infection by Beauveria bassiana and Metarhizium anisopliae on the Feeding of Uvarovistia zebra. Journal of Insect Science, 1, 88. https://doi.org/10.1093/jisesa/iev033

[140] Wu, S., Gao, Y., Zhang, Y., Wang, E. and Xu, X. (2014) An Entomopathogenic Strain of Beauveria bassiana against Frankliniella occidentalis with no Detrimental Effect on the Predatory Mite Neoseiulus barkeri: Evidence from Laboratory Bioas- 
say and Scanning Electron Microscopic Observation. PLoS ONE, 1, 1-7.

[141] Kaur, S., Kaur, P.H., Kaur, K. and Kaur, A. (2011) Effect of Different Concentrations of Beauveria bassiana on Development and Reproductive Potential of Spodoptera litura (Fabricius). Journal of Biopesticides, 2, 161-168.

https://doi.org/10.1371/journal.pone.0084732

[142] Wu, S., Youngman, R.R., Kok, L.T. and Laub, C.A. (2016) Sublethal Effect of Beauveria bassiana and Metarhizium brunneum (Hypocreales: Clavicipitaceae) on Cyclocephala lurida (Coleoptera: Scarabaeidae). Journal of Entomological Science, 1, 43-53. https://doi.org/10.18474/15-19.1

[143] Martin, P., Michal, L., Michal, N. and Juraj, S. (2016) Testing of Entomopathogenic Fungi in Biological Control against Pine Weevil. Biological and Chemical Research, 3, 1-11.

[144] Storm, C., Scoates, F., Nunn, A., Potin, O. and Dillon, A. (2016) Improving Efficacy of Beauveria bassianaagainst Stored Grain Beetles with a Synergistic Co-formulant. Insects, 42, 1-14.

[145] Tadele, S. and Emana, G. (2017) Entomopathogenic Effect of Beauveria bassiana (bals.) and Metarrhizium anisopliae (metschn.) on Tuta absoluta (meyrick) Lepidoptera: Gelechiidae) Larvae under Laboratory and Glasshouse Conditions in Ethiopia. Journal of Plant Pathology and Microbiolgy, 8, 411.

[146] Erler, F. and Ates, A.O. (2015) Potential of Two Entomopathogenic Fungi, Beauveria bassiana and Metarhizium anisopliae (Coleoptera: Scarabaeidae), as Biological Control Agents against the June Beetle. Journal of Insect Science, 1, 1-6. https://doi.org/10.1093/jisesa/iev029

[147] Siddiqui, Z. A. and Akhtar, M. S. (2008) Synergistic Effects of Antagonistic Fungi and a Plant Growth Promoting Rhizobacterium, an Arbuscular Mycorrhizal Fungus, or Composted Cow Manure on Populations of Meloidogyne incognita and Growth of Tomato. Biocontrol Science and Technology, 3, 279-290. https://doi.org/10.1080/09583150801896043

[148] Bhat, M.Y., Wani, A. and Fazal, M. (2012) Effect of Paecilomyces lilacinus and Plant Growth Promoting Rhizobacteria on Meloidogyne incognitaInoculated Black Gram, Vigna mungo Plants. Journal of Biopesticides, 1, 36-43.

[149] Adebola, M.O. and Amadi, J.E. (2010) Antagonistic Activities of Paecilomyces and Rhizopus Species against the Cocoa Black Pod Pathogen (Phytophthora palmivora). African Scientist, 4, 235-239.

[150] Ganate, M.A. and Khan, T.A. (2010) Biological Potential of Paecilomyces lilacinus on Pathogenesis of Meloidodyne javanica Infecting Tomato Plant. European Journal of Applied Sciences, 2, 80-84.

[151] Oclarit, E.L. and Cumagun, C.J.R. (2009) Evaluation of Efficacy of Paecilomyces lilacinus as Biological Control Agent of Meloidogyne incognita Attacking Tomato. Journal of Plant Protection Research, 49, 337-340. https://doi.org/10.2478/v10045-009-0053-x

[152] Torres, M.J.C., Brandan, P., Petrosellic, G., Erra-Balsellsc, R. and Audisioa, M.C. (2016) Antagonistic Effects of Bacillus subtilis subsp. subtilis and B. amyloliquefaciens against Macrophomina phaseolina: SEM Study of Fungal Changes and UV-MALDI-TOF MS Analysis of Their Bioactive Compounds. Microbiological Research, 182, 31-39. https://doi.org/10.1016/j.micres.2015.09.005

[153] Zalila-Kolsi, I., Mahmoud, A.B., Ali, H., Sellami, S., Nasfi, Z., Tounsi, S. and Jamoussi, K. (2016) Antagonist Effects of Bacillus spp. Strains against Fusarium graminearum for Protection of Durum Wheat (Triticum turgidum L. subsp. durum). 
Microbiological Research, 192, 148-158.

https://doi.org/10.1016/j.micres.2016.06.012

[154] Han, J., Shim, H., Shin, J. and Kim, K.S. (2015) Antagonistic Activities of Bacillus spp. Strains Isolated from Tidal Flat Sediment Towards Anthracnose Pathogens Colletotrichum acutatum and C. gloeosporioides in South Korea. The Plant Pathology Journal, 2, 165-175. https://doi.org/10.5423/PPJ.OA.03.2015.0036

[155] Haidar, R., Roudeta, J., Bonnarda, O., Dufoura, M.C., Corio-Costeta, M.F., Ferta, M., Gautiera, T., Deschampsa, A. and Fermaudaa, M. (2016) Screening and Modes of Action of Antagonistic Bacteria to Control the Fungal Pathogen Phaeomoniella chlamydospora Involved in Grapevine Trunk Diseases. Microbiological Research, 192, 172-184. https://doi.org/10.1016/j.micres.2016.07.003

[156] Khan, U.H., Ahmad, R., Ahmed, W., Khan, S. M. and Khan, M.A. (2001) Evaluation of the Combined Effects of Paecilomyces lilacinus and Trichoderma harzianum against Root-knot Disease of Tomato. OnLine Journal of Biological Sciences, 3, 139-142.

[157] Belete, E., Ayalew, A. and Ahmed, S. (2015) Antagonistic Effect of Native Bacillus Isolates against Black Root Rot of Faba Bean. African Crop Science Journal, 3, 249-259.

[158] Zhao, Y., Selvaraj, J.N., Xing, F., Zhou, L. and Wang, Y. (2014) Antagonistic Action of Bacillus subtilis Strain SG6 on Fusarium graminearum. PLoS ONE, 3, 1-11. https://doi.org/10.1371/journal.pone.0092486

[159] Akhtar, A., Abbasi, H. and Sharf, R. (2012) Antagonistic Effects of Pseudomonas fluorescens and Bacillus subtilis on Meloidogyne incognita Infecting Vigna mungo L. International Journal of Plant, Animal and Environmental Sciences, 1, 55-63.

[160] Wei, L., Shao, Y., Wan, J., Feng, H. and Zhu, H. (2014) Isolation and Characterization of a Rhizobacterial Antagonist of Root-Knot Nematodes. PLOS ONE, 1, 1-7. https://doi.org/10.1371/journal.pone.0085988

[161] Lemes, A.R.N., Davolos, C.C., Legori, P.C.B.C., Fernandes, O.A. and Ferre', J. (2014) Synergism and Antagonism between Bacillus thuringiensis Vip3A and Cry1 Proteins in Heliothis virescens, Diatraea saccharalis and Spodoptera frugiperda. PLOS ONE, 10, 1-10.

[162] Ajilogba, C.F., Babalola, O.O. and Ahmad, F. (2013) Antagonistic Effects of Bacillus Species in Biocontrol of Tomato Fusarium Wilt. Studies on Ethno-Medicine, 3, 205-216. https://doi.org/10.1080/09735070.2013.11886462

[163] Issazadeh, K., Rad, S.K., Zarrabi, S. and Rahimibashar, M.R. (2012) Antagonism of Bacillus Species against Xanthomonas campestris pv. campestris and Pectobacterium carotovorum subsp. carotovorum. African Journal of Microbiology Research, 6, 1615-1620.

[164] Sharififard, M., Mossadegh, M.S., Vazirianzadeh, B. and Zarei-Mahmoudabadi, A. (2001) Interactions Between Entomopathogenic Fungus, Metarhizium anisopliae and Sublethal Doses of Spinosad for Control of House Fly, Musca domestica. Iranian Journal of Arthropod-Borne Diseases, 1, 28-36.

[165] Sowjanya, S.K., Padmaja, V. and Murthy, Y.L. (2008) Insecticidal Activity of Destruxin, a Mycotoxin from Metarhizium anisopliae (Hypocreales), against Spodoptera litura (Lepidoptera: Noctuidae) Larval Stages. Pest Management Science, 2, 119-125. https://doi.org/10.1002/ps.1480

[166] Lozano-Tovar, M.D., Garrido-Jurado, I., Lafont, F. and Quesada-Moraga, E. (2015) Insecticidal Activity of a Destruxin-containing Extract of Metarhizium brunneumagainst Ceratitis capitate (Diptera: Tephritidae). Journal of Economic Entomolo- 
gy, 2, 462-472. https://doi.org/10.1093/jee/tov041

[167] Nabaei, N., Mehrvar, A., Saber and Bagheri, M. (2012) Efficacy of Entomopathogenic Fungi in Combination with Diatomaceous Earth against Callosobruchus maculatus (Coleoptera: Bruchidae). Acta Entomologia Sinica, 55, 1282-1288.

[168] Bugeme, D.M., Knapp, M., Ekesi, S., Chabi-Olaye, A., Boga, H.I. and Maniania, N.K. (2015) Efficacy of Metarhizium anisopliae in Controlling the Two-Spotted Spider Mite Tetranychus urticae on Common Bean in Screenhouse and Field Experiments. Insect Science, 22, 121-128. https://doi.org/10.1111/1744-7917.12111

[169] Mehinto, J.T., Atachi, P., Kpindou, O.K.D., Dannon, E.A. and Tamò, M. (2014) Mortality of Maruca vitrata (Lepidoptera: Crambidae) Larval Stages Induced by Different Doses of the Entomopathogenic Fungi Metarhizium anisopliae and Beauveria bassiana. International Journal of Advanced Research, 4, 273-285.

[170] Contreras, J., Mendoza, J.E., Martínez-Aguirre, M.R., García-Vidal, L., Izquierdo, J. and Bielza, P. (2013) Efficacy of Entomopathogenic Fungus Metarhizium anisopliae against Tuta absoluta (Lepidoptera: Gelechiidae). Journal of Economic Entomology, $1,121-124$.

[171] Priyaja, P., Jayesh, P., Correya, N.S., Sreelakshmi, B., Sudheer, N.S., Philip, R. and Singh, I.S.B. (2014) Antagonistic Effect of Pseudomonas aeruginosa Isolates from Various Ecological Niches on Vibrio Species Pathogenic to Crustaceans. Journal of Coastal Life Medicine, 1, 76-84.

[172] Prasad, R., Chandra, H., Sinha, B. K. and Srivastava, J. (2015) Antagonistic Effect of Pseudomonas fluorescens Isolated from Soil of Doon Valley (Dehradun-India) on Certain Phyto-Pathogenic Fungi. Octa Journal of Biosciences, 2, 92-95.

[173] Sivanantham, T., Rasaiyah, V., Satkunanathan, N. and Thavaranjit, A.C. (2013) In Vitro Screening of Antagonistic Effect of Soil Borne Bacteria on Some Selected Phytopathogenic Fungi. Archives of Applied Science Research, 1, 1-4.

[174] Maurya, M.K., Singh, R. and Tomer, A. (2014) In Vitro Evaluation of Antagonistic Activity of Pseudomonas fluorescensagainst Fungal Pathogen. Journal of Biopesticides, 1, 43-46.

[175] Khokhar, I., Haider, S.M., Ali, A., Mukhtar, I. and Mushtaq, S. (2011) Evaluation of Antagonistic Activity of Soil Bacteria against Plant Pathogenic Fungi. Pakistan Journal of Phytopathology, 2, 166-169.

[176] Bouhous, M. and Larous, L. (2012) Efficiency of the Entomopathogenic Fungus Verticillium lecanii in the Biological Control of Trialeurodes vaporariorum, (Homoptera: Aleyrodidae), a Greenhouse Culture Pest. African Journal of Microbiology Research, 10, 2435-2442.

[177] Xu, D., Ali, S., Huang, Z., Zhou, F.C., Afzal, M. and Bashir, M.H. (2009) Influence of the Entomopathogenic Fungus, Verticillium lecanii on the Whitefly Predator, Axinoscymnuscardilobus (Coleoptera: Coccinellidae) under Laboratory Conditions. Pakistan Journal of Zoology, 4, 289-295.

[178] Elzinga, J.A., Biere, A. and Harvey, J.A. (2002) The Rearing of the Gregarious Koinobiont Endoparasitoid Microplitis tristis (Hymenoptera: Braconidae) on Its Natural Host Hadena bicruris (Lepidoptera: Noctuidae). Proceedings Section Experimental and Applied Entomology of the Netherlands Entomological Society, 13, 109-115.

[179] Morales-Ramos, J.A. and Rojas, M.G. (2014) A Modular Cage System Design for Continuous Medium to Large Scale in Vivo Rearing of Predatory Mites (Acari: Phytoseiidae). https://doi.org/10.1155/2014/596768

[180] Silva, F.R., Moraes, G.J., Gondim, M.G.C., Knapp, M., Rouam, S.L., Paes, J.L.A. and 
Oliveira, G.M. (2010) Efficiency of Phytoseiulus longipes Evans as a Control Agent of Tetranychus evansi Baker \& Pritchard (Acari: Phytoseiidae: Tetranychidae) on Screenhouse Tomatoes. Neotropical Entomology, 6, 991-995. https://doi.org/10.1590/S1519-566X2010000600022

[181] Lee, W., Ho, C. and Lo, K. (1990) Mass Production of Phytoseiids: Evaluation of Eight Host Plants for the Mass-Rearing of Tetranychus urticae and T. kanzawai Kishda (Acarina: Tetranychidae). Agricultural Sciences in China, 2, 121-132.

[182] Khanamani, M., Fathipour, B.Y., Talebi, A.A. and Mehrabadi, M. (2017) Evaluation of Different Artificial Diets for Rearing the Predatory Mite Neoseiulus californicus (Acari: Phytoseiidae): Diet-Dependent Life Table Studies. Acarologia, 2, 407-419. https://doi.org/10.1051/acarologia/20174165

[183] Steinberg, S. (2013) Novel Technologies in Mass Rearing of Beneficial Arthropods. Proceedings of the Annual Biocontrol Industry Meeting, Bael, 1-28.

[184] Fernando, L.C.P., Aratchige, N.S., Kumari, S.L.M.L., Appuhamy, P.A.L.D. and Hapuarachchi, D.C.L. (2006) Developmet of a Method for Mass Rearing of Neoseiulus baraka, a Mite Predatory on the Coconut Mite, Aceria guerreronis. The Journal of the Coconut Research Institute of Sri Lanka, 16, 22-36.

[185] Grenier, S. (2012) Artificial Rearing of Entomophagous Insects, with Emphasis on Nutrition and Parasitoids-General Outlines from Personal Experience. Karaelmas Science and Engineering Journal, 2, 1-12. https://doi.org/10.7212/zkufbd.v2i2.97

[186] Grenier, S. (2009) In Vitro Rearing of Entomophagous Insects-Past and Future Trends: A Minireview. Bulletin of Insectology, 1, 1-6.

[187] Xu, X. and Enkegaard, A. (2010). Prey Preference of the Predatory Mite, Amblyseius swirskii between First Instar Western Flower Thrips Frankliniella occidentalis and Nymphs of the Two-Spotted Spider Mite Tetranychus urticae. Journal of Insect Science, 149, 1-11. https://doi.org/10.1673/031.010.14109

[188] Fiedler, Z. (2012) Interaction between Beneficial Organisms in Control of Spider Mite Tetranychus urticae (koch.) Journal of Plant Protection Research, 2, 226-229. https://doi.org/10.2478/v10045-012-0035-2

[189] Hoque, F.M., Islam, M.W. and Khalequzzaman, M. (2010) Functional Eesponse of Phytoseiulus persimilis Athias-Henriot to Tetranychus urticae Koch: Effects of Prey Life Stages and Temperature. University Journal of Zoology, Rajshahi University, 29, 1-8.

[190] Rhodes, M.E. and Liburd, O.E. (2006) Evaluation of Predatory Mites and Acramite for Control of Two-spotted Spider Mites in Strawberries in North Central Florida. Journal of Economic Entomology, 4, 1291-1298. https://doi.org/10.1093/jee/99.4.1291

[191] Elmoghazy, M.M.E., El-Saiedy, E.M.A. and Romeih, A.H.M. (2012) Integrated Control of the Two-spotted Spider Mite Tetranychus urticae Koch (Acari: Tetranychidae) on Faba Bean Vicia faba (L.) in an Open Field at Behaira Governorate, Egypt. International Journal of Environmental Science and Engineering, 2, 93-100.

[192] Takano-Lee, M. and Hoddle, M. (2002) Predatory Behaviors of Neoseiulus californicus and Galendromus helveolus (Acari: Phytoseiidae) Attacking Oligonychus perseae (Acari: Tetranychidae). Experimental and Applied Acarology, 26, 13-26. https://doi.org/10.1023/A:1020949531639

[193] Arthurs, S., McKenzie, C.L., Chen, J., Dogramaci, M., Brennan, M., Houben, K. and Osborne, L. (2009) Evaluation of Neoseiulus cucumeris and Amblyseius swirskii (Acari: Phytoseiidae) as Biological Control Agents of Chilli Thrips, Scirtothrips dorsalis (Thysanoptera: Thripidae) on Pepper. Biological Control, 49, 91-96. 
https://doi.org/10.1016/j.biocontrol.2009.01.002

[194] Vá Squez, G.M., Orr, D.B. and Baker, J.R. (2006) Efficacy Assessment of Aphidius colemani (Hymenoptera: Braconidae) for Suppression of Aphis gossypii (Homoptera: Aphididae) in Greenhouse-grown Chrysanthemum. Journal of Economic Entomology, 4, 1104-1111. https://doi.org/10.1093/jee/99.4.1104

[195] Maharjan, B., Kwon, M., Kim, J. and Jung, C. (2017) Mass Production of Diglyphus isaea (Hymenoptera: Eulophidae), a Biological Control Agent of a Korean Population of Potato Leaf Miner Liriomyza huidobrensis (Blanchard) (Diptera: Agromyzidae). Entomological Research, 2, 94-100. https://doi.org/10.1111/1748-5967.12205

[196] Dai, P., Ruan, C., Zang, L., Wan, F. and Liu, L. (2014) Effects of Rearing Host Species on the Host-feeding Capacity and Parasitism of the Whitefly Parasitoid Encarsia formosa. Journal of Insect Science, 118, 1-10. https://doi.org/10.1093/jis/14.1.118

[197] Moreno-Ripoll, R., Gabarra, R., Symondson, W.O.C., King, R.A. and Agustí, N. (2012) Trophic Relationships between Predators, Whiteflies and Their Parasitoids in Tomato Greenhouses: A Molecular Approach. Bulletin of Entomological Research, 102, 415-423. https://doi.org/10.1017/S0007485311000836

[198] Dubey, M., Thind, T.S., Dubey, R.K. and Jindal, S.K. (2016) Efficacy of Plant Extracts against Tomato Late Blight under Net House Conditions. Indian Journal of Ecology, 1, 375-377.

[199] Goufo, P., Mofor, T.C., Fontem, D.A. and Ngnokam, D. (2008) High Efficacy of Extracts of Cameroon Plants against Tomato Late Blight Disease. Agronomy for Sustainable Development, 4, 567-573. https://doi.org/10.1051/agro:2008036

[200] Ademe, A., Ayalew, A. and Woldetsadik, K. (2013). Evaluation of Antifungal Activity of Plant Extracts against Papaya Anthracnose (Colletotrichum gloeosporioides). Plant Pathology \& Microbiology, 10, 1-4. https://doi.org/10.4172/2157-7471.1000207

[201] Jahangiriana, H., Haron, M.D.J., Mohd, H.S.I.A., Roshanak, R., Leili, A.D.Y.A.E., Majid, R.C. and Nazanin, V. (2013) Well Diffusion Method for Valuation of Antibacterial Activity of Copper Phenyl Fatty Hydroxamate Synthesized from Canola and Palm Kernel Oils. Digest Journal of Nanomaterials and Biostructures, 3, 1263-1270.

[202] Nashwa, S.M.A. and Abo-Elyousr, A.M.K. (2012) Evaluation of Various Plant Extracts against the Early Blight Disease of Tomato Plants under Green House and Field Conditions. Plant Protection Science, 2, 74-79. https://doi.org/10.17221/14/2011-PPS

[203] Hassanein, M.N., Abou, Z.M.A., Youssef, A.K. and Mahmoud, A.D. (2010) Control of Tomato Early Blight and Wilt using Aqueous Extract of Neem Leaves. Phytopathologia Mediterranea, 49, 143-151.

[204] Sahu, D.K., Khare, C.P. and Patel, R. (2014) Eco-Friendly Management of Early Blight of Tomato Using Botanical Plant Extracts. Journal of Industrial Pollution Control, 2, 215-218.

[205] Karimi, K., Amini, J., Harighi, B. and Bahramnejad, B. (2012) Evaluation of Biocontrol Potential of Pseudomonas and Bacillus spp against Fusarium Wilt of Chickpea. Australian Journal of Crop Science, 6, 695-703.

[206] Naing, W.K., Anees, M., Nyugen, H.X., Lee, S.Y., Jeon, W.S., Kim, Y.S., Kim, H.M. and Kim, Y.K. (2013) Biocontrol of Late Blight Diseases (Phytophthora Capsici) of Pepper and the Plant Growth Promotion by Paenibacillus chimensis KWNJ8. Journal of Phytopathology, 2, 164-165.

[207] Hossain, M. A., ALsabari, K. M., Weli, A.M. and Al-Riyami, Q. (2013) Gas Chro- 
matography-Mass Spectrometry Analysis and Total Phenolic Contents of Various Crude Extracts from the Fruits of Datura metel L. Journal of Taibah University for Science, 7, 209-215. https://doi.org/10.1016/j.jtusci.2013.06.004

[208] Araújo, K.M., Lima, A., Silva, J.N., Rodrigues, L.L., Amorim, A.G.N., Quelemes, P.V., Santos, R.C., Rocha, J.C., Andrades, E.O., Leite, J.R.S.A., Mancini-Filho, J. and Trindade, R.A. (2014) Identification of Phenolic Compounds and Evaluation of Antioxidant and Antimicrobial Properties of Euphorbia tirucalli L. Antioxidants, 3, 159-175. https://doi.org/10.3390/antiox3010159

[209] Khater, H.F. (2012) Prospects of Botanical Biopesticides in Insect Pest Management. Pharmacologia, 12, 641-656.

[210] Cawoy, H., Wagner, B., Fickers, P. and Ongena, M. (2011). Bacillus-Based Biological Control of Plant Diseases, Pesticides in the Modern World-Pesticides Use and Management. Dr. Margarita Stoytcheva (Ed.), ISBN: 978-953-307-459-7, InTech, Available from:

http://www.intechopen.com/books/pesticides-in-themodern-world-pesticides-use-a nd-management/bacillus-based-biological-control-of-plant-diseases

[211] Iberê, F.S., Oliveira, R.G., Soares, I.M., Alvim, T.C., Ascêncio, S.D. and Martins, D.T.O. (2014) Evaluation of Acute Toxicity, Antibacterial Activity, and Mode of Action of the Hydro Ethanolic Extract of Piper umbellatum L. Journal of Ethnopharmacology, 151, 137-143. https://doi.org/10.1016/j.jep.2013.10.011

[212] El-Wakeil, N.E. (2013) Botanical Pesticides and their Mode of Action. Gesunde Pflanzen, 65, 125-149. https://doi.org/10.1007/s10343-013-0308-3

[213] Rodino, S., Butu, A., Butu, M. and Cornea, C.P. (2012) In Vitro Efficacy of some Plant Extracts against Damping off Disease of Tomatoes. Journal of International Scientific Publications: Agriculture and Food, 2, 240-244.

[214] Moreira, M.D., Picanço, M.C., Barbosa, L.C.A., Guedes, R.N.C., Campos, M.R., Silva, G.A. and Martins, J.C. (2007) Plant Compounds Insecticide Activity against Coleoptera Pests of Stored Products. Pesquisa Agropecuária Brasileira, 7, 909-915. https://doi.org/10.1590/S0100-204X2007000700001

[215] Akrami, M., Golzary, H. and Ahmadzadeh, M. (2011) Evaluation of Different Combinations of Trichoderma Species for Controlling Fusarium Rot of Lentil. African Journal of Biotechnology, 14, 2653-2658.

[216] Błaszczyk, L., Siwulski, M., Sobieralski, K., Lisiecka, J. and Jędryczka, M. (2014) Trichoderma spp.-Application and Prospects for Use in Organic Farming and Industry. Journal of Plant Protection Research, 4, 309-317.

[217] Kokalis-Burelle, N. (2015) Pasteuria penetrans for Control of Meloidogyne incognita on Tomato and Cucumber, and M. arenaria on Snap Dragon. The Journal of Nematology, 3, 207-213.

[218] Mendoza, J.L.H., Pérez, M.I.S., Prieto, J.M.G., Velásquez, J.D.Q., Olivares, J.G.G. and Langarica, H.R.G. (2015) Antibiosis of Trichoderma spp Strains Native to Northeastern Mexico against the Pathogenic Fungus Macrophomina phaseolina. Brazilian Journal of Microbiology, 4, 1093-1101. https://doi.org/10.1590/S1517-838246420120177

[219] Pal, K.K. and McSpadder, G.B. (2006) Biological Control of Plant Pathogens. The Plant Health Instructor, 10, 1-25. https://doi.org/10.1094/PHI-A-2006-1117-02

[220] Xiao, Y., Wei, X., Ebright, R. and Wall, D. (2011) Antibiotic Production by Myxobacteria Plays a Role in Predation. Journal of Bacteriology, 18, 4626-4633.

https://doi.org/10.1128/JB.05052-11

[221] Refki, E., Sadok, B.M., Ali, B.B., Faouzi, A., Jean, V.F. and Rudy, C.M. (2016) Effec- 
tiveness of Pheromone Traps against Tuta absoluta. Journal of Entomology and Zoology Studies, 6, 841-844.

[222] Chermiti, B. and Abbes, K. (2012) Comparison of Pheromone Lures Used in Mass Trapping to Control the Tomato Leafminer Tuta absoluta (Meyrick, 1917) in Industrial Tomato Crops in Kairouan (Tunisia). EPPO Bulletin, 2, 241-248. https://doi.org/10.1111/epp.2561

[223] Rao, K.S., Vishnupriya, R. and Ramaraju, K. (2017) Efficacy and Safety Studies on Predatory Mite, Neoseiulus longispinosus (Evans) against Two-Spotted Spider Mite, Tetranychusurticae Koch under Laboratory and Greenhouse Conditions. Journal of Entomology and Zoology Studies, 4, 835-839.

[224] Khan, A.I., Hussain, S., Akbar, R., Saeed, M., Farid, A., Ali, I., Alam, M. and Shah, B. (2015) Efficacy of a Biopesticide and Synthetic Pesticides against Tobacco Aphid, Myzus persicae Sulz. (Homoptera, Aphididae), on Tobacco in Peshawar. Journal of Entomology and Zoology Studies, 4, 371-373.

[225] Ahmad, S., Khan, I.A., Hussain, Z., Shah, S.I.A. and Ahmad, M. (2007) Comparison of a Biopesticide with Some Synthetic Pesticides against Aphids in Rapeseed Crop. Sahrad Journal of Agriculture, 4, 1117-1120.

[226] Shah, J.A., Inayatullah, M., Sohail, K., Shah, S.F., Shah, S., Iqbal, T. and Usman, M. (2013) Efficacy of Botanical Extracts and a Chemical Pesticide against Tomato Fruit Worm, Helicoverpa armigera. Sarhad Journal of Agriculture, 1, 93-96.

[227] Kenis, M., Hurley, B.P., Hajek, A.E. and Cock, M.J.W. (2017) Classical Biological Control of Insect Pests of Trees: Facts and Figures. Biological Invasions, 19, 34013417. https://doi.org/10.1007/s10530-017-1414-4

[228] Galko, J., Nikolov, C., Kunca, A., Vakula, J., Gubka, A., Zúbrik, M., Rell, S. and Konôpka, B. (2016) Effectiveness of Pheromone Traps for the European Spruce Bark Beetle: AComparative Study of Four Commercial Products and Two New Models. Lesnícky Časopis-Forestry Journal, 62, 207-215. https://doi.org/10.1515/forj-2016-0027

[229] Hussain, F., Abid, M., Shaukat, S., Farzana, S. and Akbar, M. (2015) Anti-Fungal Activity of Some Medicinal Plants on Different Pathogenic Fungi. Pakistan Journal of Botany, 5, 2009-2013.

[230] Sidhu, S.H., Kumar, V. and Madhu, M.R. (2017) Eco-Friendly Management of Root-Knot Nematode, Meloidogyne javanica in Okra (Abelmoschus esculentus) Crop. International Journal of Pure and Applied Bioscience, 1, 569-574. https://doi.org/10.18782/2320-7051.2507

[231] Aw, K.M.S. and Hue, S.M. (2017) Mode of Infection of Metarhizium spp. Fungus and Their Potential as Biological Control Agents. Journal of Fungi, 30, 1-20.

https://doi.org/10.3390/jof3020030

[232] Ngegba, P.M., Kanneh, S.M., Bayon, M.S., Ndoko, E.J. and Musa, P.D. (2018) Fungicidal Effect of Three Plants Extracts in Control of Four Phytopathogenic Fungi of Tomato (Lycopersicum esculentum L.) Fruit Rot. International Journal of Environment, Agriculture and Biotechnology, 1, 112-117.

https://doi.org/10.22161/ijeab/3.1.14

[233] Patrice, A.K., Séka, K., Francis, Y.K., Théophile, A.S., Fatoumata, F. and Diallo, H.A. (2017) Effects of Three Aqueous Plant Extracts in the Control of Fungi Associated with Post-harvest of Yam (Dioscorea alata). International Journal of Agronomy and Agricultural Research, 3, 77-87.

[234] Devi, K.B., Pavankumar, P. and Bhadraiah, B. (2017) Antifungal Activity of Plant Extracts against Post-Harvest Fungal Pathogens. International Journal of Current 
Microbiology and Applied Sciences, 6, 669-679. https://doi.org/10.20546/ijcmas.2017.601.081

[235] Minz, S., Samuel, C.O. and Tripathi, C.S. (2012) The Effect of Plant Extracts on the Growth of Wilt Causing Fungi Fusarium oxysporum. Journal of Pharmacy and Biological Sciences, 1, 13-16. https://doi.org/10.9790/3008-0411316

[236] Sumitra, A., Kanojia, A.K., Kumar, A., Mogha, N. and Sahu, V. (2014) Biopesticide Formulation to Control Tomato Lepidopteran Pest Menace. Current Science, 7, 1051-1057.

[237] Muzemu, S., Mvumi, B.M., Nyirenda, S.P.M., Sileshi, G.W., Sola, P., Chikukura, L., Kamanula, J.F., Belmain, S.R. and Stevenson, P.C. (2011) Pesticidal Effects of Indigenous Plant Extracts against Rape Aphids and Tomato Red Spider Mites. African Crop Science Conference Proceedings, 10, 171-173.

[238] Nia, B., Frah, N. and Azoui, I. (2015) Insecticidal Activity of Three Plants Extracts against Myzuspersicae (Sulzer, 1776) and Their Phytochemical Screening. Acta Agriculturae Slovenica, 2, 261-267. https://doi.org/10.14720/aas.2015.105.2.09

[239] Parte, S.G., Kharat, A.S., Mohekar, A.D., Chavan, J.A., Jagtap, A.A., Mohite, A.K. and Patil, R.N. (2015) Efficacy of Plant Extracts for Management of Cimex lectularius (Bed Bug). International Journal of Pure and Applied Bioscience, 3, 506-508.

[240] Oyedokun, A.V., Anikwe, J.C., Okelana, F.A., Mokwunye, I.U. and Azeez, O.M. (2011) Pesticidal Efficacy of Three Tropical Herbal Plants' Leaf Extracts against Macrotermes bellicosus, an Emerging Pest of Cocoa, Theobroma cacao L. Journal of Biopesticides, 2, 131-137.

[241] Barbosa, F.S., Leite, G.L.D., Martins, E.R., D’avila, V.A. and Cerqueira, V.M. (2013) Medicinal Plant Extracts on the Control of Diabrotica speciosa (Coleoptera: Chrysomelidae). Brazilian Journal of Medicinal Plants, 1, 142-149.

[242] Islam, M.R., Jeong, Y.T., Lee, Y.S. and Song, C.H. (2012) Isolation and Identification of Antifungal Compounds from Bacillus subtilis C9 Inhibiting the Growth of Plant Pathogenic Fungi. Mycobiology, 1, 59-66. https://doi.org/10.5941/MYCO.2012.40.1.059

[243] Anitha, A. and Rabeeth, M. (2009) Control of Fusarium Wilt by Bioformulation of Streptomyces griseus in the Green House Condition. African Journal of Basic and Applied Sciences, 1-2, 9-14.

[244] Selim, H.M.M., Gomaa, N.M. and Essa, A.M.M. (2016) Antagonistic Effect of Endophytic Bacteria against Some Phytopathogens. Egyptian Journal of Botany, 1, 74-81.

[245] Islam, M.R., Mondal, C., Hossain, I. and Meah, B.M. (2014) Compost Tea as Soil Drench: An Alternative Approach to Control Bacterial Wilt in Brinjal. Archives of Phytopathology and Plant Protection, 12, 1475-1488. https://doi.org/10.1080/03235408.2013.847654

[246] Islam, M.R., Mondal, C., Hossain, I. and Meah, B.M. (2013) Organic Management: An Alternative to Control Late Blight of Potato and Tomato Caused by Phytophthora infestans. International Journal of Theoretical \& Applied Sciences, 2, 32-42.

[247] Pane, C., Palese, A.M., Celano, G. and Zaccardelli, M. (2014) Effects of Compost Tea Treatments on Productivity of Lettuce and Kohlrabi Systems under Organic Cropping Management. Italian Journal of Agronomy, 3, 1-4. https://doi.org/10.4081/ija.2014.596

[248] Sarles, L., Verhaeghe, A., Francis, F. and Verheggen, F.J. (2015) Semiochemicals of Rhagoletis Fruit Flies: Potential for Integrated Pest Management. Crop Protection, 78, 114-118. https://doi.org/10.1016/j.cropro.2015.09.001 
[249] Powell, W. and Pickett, J.A. (2003) Manipulation of Parasitoids for Aphid Pest Management: Progress and Prospects. Pest Management Science, 59, 149-155. https://doi.org/10.1002/ps.550

[250] Leng, P., Zhang, Z., Pan, G. and Zhao, M. (2011) Applications and Development Trends in Biopesticides. African Journal of Biotechnology, 86, 19864-19873.

[251] Okunlola, A.I. and Akinrinnola, O. (2014) Effectiveness of Botanical Formulations in Vegetable Production and Bio-Diversity Preservation in Ondo State, Nigeria. Journal of Horticulture and Forestry, 1, 6-13.

[252] Shiberu, T. and Getu, E. (2016). Assessment of Selected Botanical Extracts against Liriomyza Species (Diptera: Agromyzidae) on Tomato under Glasshouse Condition. International Journal of Fauna and Biological Studies, 1, 87-90.

[253] Nawaz, M., Mabubu, J.I. and Hua, H. (2016) Current Status and Advancement of Biopesticides: Microbial and Botanical Pesticides. Journal of Entomology and Zoology Studies, 2, 241-246.

[254] Srijita, D. (2015) Biopesticides: An Eco-friendly Approach for Pest Control. World Journal of Pharmacy and Pharmaceutical Sciences, 6, 250-265.

[255] Sesan, T.E., Enache, E., Iacomi, M., Oprea, M., Oancea, F. and Iacomi, C. (2015) Antifungal Activity of some Plant Extract against Botrytis cinerea Pers. in the Blackcurrant Crop (Ribes nigrum L). Acta Scientiarum Polonorum Technologia Alimentaria, 1, 29-43.

[256] Kawalekar, J.S. (2013) Role of Biofertilizers and Biopesticides for Sustainable Agriculture. Journal of Bio Innovation, 2, 73-78.

[257] Stoneman, B. (2010) Challenges to Commercialization of Biopesticides. Proceedings Microbial Biocontrol of Arthropods, Weeds and Plant Pathogens: Risks, Benefits and Challenges. National Conservation Training Center, Shepherdstown, WV.

[258] Javaid, M.K., Ashiq, M. and Tahir, M. (2016) Potential of Biological Agents in Decontamination of Agricultural Soil. https://doi.org/10.1155/2016/1598325

[259] Sales, M.D.C., Costa, H.B., Fernandes, P.M.B., Ventura, J.A. and Meira, D.D. (2016) Antifungal Activity of Plant Extracts with Potential to Control Plant Pathogens in Pineapple. Asian Pacific Journal of Tropical Biomedicine, 1, 26-31. https://doi.org/10.1016/j.apjtb.2015.09.026

[260] Gerson, U. (2014) Pest Control by Mites (acari): Present and Future. Acarologia, 4, 371-394. https://doi.org/10.1051/acarologia/20142144

[261] Lanzoni, A., Martelli, R. and Pezzi, F. (2017) Mechanical Release of Phytoseiulus persimilis and Amblyseius swirskii on Protected Crops. Bulletin of Insectology, 2, 245-250.

[262] Gupta, S. and Dikshit, A.K. (2010) Biopesticides: An Ecofriendly Approach for Pest Control. Journal of Biopesticides, 1, 186-188.

[263] Kumar, S. and Singh, A. (2015) Biopesticides: Present Status and the Future Prospects. Journal of Fertilizers \& Pesticides, 2, 1-2. https://doi.org/10.4172/2471-2728.1000e129 